\title{
Tracking biochemical changes during adventitious root formation in olive (Olea europaea L.)
}

Sara Porfirio ${ }^{1,5}$, Maria Leonilde Calado ${ }^{2}$, Carlos Noceda ${ }^{1,3}$, Maria João Cabrita ${ }^{6}$, Marco Gomes da Silva ${ }^{4}$, Parastoo Azadi ${ }^{5}$, Augusto Peixe ${ }^{6 *}$

${ }^{1}$ Instituto de Ciências Agrárias e Ambientais Mediterrânicas/Instituto de Investigação e Formação Avançada ICAAM/IIFA , Universidade de Évora, 7002-554 Évora, Portugal

2 INIAV - Instituto Nacional de Investigação Agrária e Veterinária, Estrada de Gil Vaz, Apartado 6, 7351-901 Elvas, Portugal

3 Universidad Estatal de Milagro (UNEMI), Departamento de Investigación-Facultad de Ingeniería, Cdla. Universitaria, vía Milagro Km. 26, Milagro, Ecuador

${ }^{4}$ LAQV, REQUIMTE, Departamento de Química, Faculdade de Ciências e Tecnologia, Universidade Nova de Lisboa, 2829-516 Caparica, Portugal

${ }^{5}$ Complex Carbohydrate Research Center, The University of Georgia, 315 Riverbend Road, Athens, Georgia 30602

${ }^{6}$ Escola de Ciências e Tecnologia, Instituto de Ciências Agrárias e Ambientais Mediterrânicas Universidade de Évora, 7002-554 Évora, Portugal

Corresponding author

*E-mail: apeixe@uevora.pt

Phone: +351266 760821

Fax: +352266760821

(C) 2016. This manuscript version is made available under the Elsevier user license http://www.elsevier.com/open-access/userlicense/1.0/ 


\section{Abstract}

The activity of oxidative enzymes and the levels of free auxins were determined during adventitious root formation in olive explants. Rooting trials were performed both with in vitro-cultured microshoots of the cultivar 'Galega Vulgar', treated with indole-3-butyric acid (IBA) and with salicylhydroxamic acid (SHAM)

+ IBA, as well as with semi-hardwood cuttings of the cultivars 'Galega Vulgar' (difficult-to-root) and 'Cobrançosa' (easy-to-root), treated with IBA. The auxin (IBA) was used in all experiments as a rooting promoter, while SHAM was used in micropropagation trials as rooting inhibitor, providing a negative control. Free indole-3-acetic acid (IAA) and IBA concentrations were determined in microshoots, as well as in semi-hardwood cuttings, throughout the rooting period at pre-established time-points. At the same time-points, the enzymatic activity of polyphenol oxidases (PPO), peroxidases (POX), and IAA oxidase (IAAox) was evaluated in the microshoots. Microshoots treated with SHAM+IBA revealed higher POX and IAAox activity, as well as lower PPO activity, than those treated only with IBA. IAA levels were higher in IBA-treated microshoots during induction phase, but lower during early initiation phase. In contrast, free IBA levels were higher in microshoots treated with SHAM+IBA during induction, but lower during initiation. A similar pattern of free auxin levels was observed in semi-hardwood cuttings of the two contrasting cultivars under evaluation. The similarities found on the auxin patterns of microshoots treated with SHAM and those of semi-hardwood cuttings of the difficult-to-root olive cultivar allow considering SHAM a reliable control for when simulation of a difficult-to-root behavior is necessary. The inhibitory effect of SHAM in root formation could be related with 1) the inhibition of alternative oxidase (AOX), leading to a downregulation of phenylpropanoid biosynthetic pathways, which would decrease the concentration of phenolic substrates for PPO; 2) an increase in IAAox activity resulting in lower free IAA levels or; 3) a defective conversion of IBA into IAA.

Keywords: indole-3-acetic acid (IAA); indole-3-butyric acid (IBA); oxidative enzymes; phenylpropanoid biosynthetic pathway; salicylhydroxamic acid (SHAM) 


\section{Introduction}

2

3

4
Olive (Olea europaea L.) is one of the main crops in the Mediterranean basin, and its production area is expanding as a result of an increase in olive oil consumption worldwide. Olive trees are mainly propagated by cuttings, a process dependent on the ability to form new adventitious roots. However, some important cultivars display a difficult-to-root behavior (Fouad et al., 1990). A scientific answer able to explain this contrasting performance among cultivars is still unavailable despite all the research done on the subject. Adventitious root formation can be divided in three physiological phases: i) induction, comprising molecular and biochemical events and corresponding to a period preceding any visible histological modifications, ii) initiation, which starts when the first histological events take place, like root primordia organization, being characterized by the occurrence of small cells with large nuclei and dense cytoplasm and iii) expression, that involves the development of the typical dome shape structures, intra-stem growth and emergence of root primordia (Pacurar et al., 2014). In olive, induction phase corresponds to the first $96 \mathrm{~h}$ after microshoot treatment, initiation corresponds to the period between 96 - $336 \mathrm{~h}$ and is followed by expression of roots thereafter (Macedo et al., 2013).

Among the factors that may influence adventitious rooting (reviewed in Porfirio et al., 2016a), oxidative enzymes and auxins are the most studied and discussed. The involvement of auxins in adventitious rooting has been studied for a long time (Wiesman et al., 1989) and they are extensively used in plant propagation protocols as root-inducing compounds (Preece, 2003). The two main natural auxins are indole-3-acetic acid (IAA) and indole-3-butyric acid (IBA), quantified by various methods, as recently revised by Porfirio et al. (2016b). Evidence suggests that IAA possibly promotes adventitious rooting through a signaling network similar to that happening in lateral roots, involving auxin response factors (ARF) and other plant hormones (Porfirio et al., 2016a). On the other hand, IBA auxin activity seems to be a result of its conversion into IAA (Korasick et al., 2013) by peroxissomal enzymes (Strader and Bartel, 
25 performance, changes in auxin concentration have been associated both with the interdependent phases of the process and with the rooting capacity of a species or cultivar (Ayoub and Qrunfleh, 2008; Nag et al., 2001). According to De Klerk et al. (1995), the high auxin levels needed for the success of induction phase become inhibitory during root expression, possibly because high auxin concentrations inhibit root elongation and promote cellular differentiation (Li et al., 2009a). This ultimately implies that IAA catabolism is mandatory to avoid the inhibition of root development..

Oxidative enzymes have long been related to adventitious root formation. Peroxidases (POX) are a group of hemic proteins that catalyze the oxidation of diverse electron donors, such as phenolic compounds and IAA (Bandurski et al., 1995; Hiraga et al., 2001), using hydrogen peroxide $\left(\mathrm{H}_{2} \mathrm{O}_{2}\right)$ as oxidative agent (Dawson, 1988). A group of POX isoforms, commonly known as IAA-oxidase (IAAox), is considered to be responsible for the enzymatic oxidative decarboxylation of IAA (Ljung et al., 2002) and the activity of this group of enzymes has been largely associated with adventitious rooting (Bansal and Nanda, 1981; Güneş, 2000). In fact, three homologous POX isoforms - PRX33, PRX34 and PRX37 - have already been identified as IAAox isoforms in Arabidopsis (Passardi et al., 2006; Pedreira et al., 2011). Polyphenol oxidases (PPO) are a group of copper-containing oxidative enzymes that catalyze two different reactions: hydroxylation of monophenols to o-diphenols (Mayer, 2006) and oxidation of 0 diphenols to o-quinones (Constabel and Barbehenn, 2008). In addition to mono- and di-phenols, PPO are

42 also capable of degrading other phenolic compounds, structurally more complex, such as anthocyanins 43 and other polyphenols (Jiménez and García-Carmona, 1999), and their involvement in adventitious 44 rooting has also been studied previously (Macedo et al., 2013; Porfirio et al., 2016a). 
47 or signaling (Zhang et al., 2014).. The ftsh4-4 mutants showed growth and developmental deficiencies,

48 including lower IAA levels and higher $\mathrm{H}_{2} \mathrm{O}_{2}$ levels, which were attributed to a higher POX gene 49 expression, activity and isozyme content. A higher-than-normal POX content and activity would affect

50 auxin levels which, in turn, would result in growth defects. This conclusion was corroborated by the fact

51 that in ftsh4-4 mutants the most highly expressed POX genes were the IAAox isoforms PRX33, PRX34

52 and PRX37 (Zhang et al., 2014).

53 In this work, the temporal changes in free auxin levels and oxidative enzymes activity were evaluated

54 during adventitious root formation in microshoots and semi-hardwood cuttings of two Portuguese olive

55 cultivars; 1) 'Galega Vulgar', which usually presents average rooting rates of $5-20 \%$ when semi-

56 hardwood cuttings are used, but can achieve 60-90\% rooting under optimized conditions for in vitro

57 culture (Peixe et al., 2010); 2) 'Cobrançosa', which is considered easy-to-root by semi-hardwood

58 cuttings, with common rooting rates higher than $70 \%$ (Santos et al., 2013), being until now recalcitrant

59 to in vitro establishment. This work is aiming to compare two contrasting behaviors concerning root

60 formation using two types of plant material (microshoots and semi hardwood cuttings). For semi-

61 hardwood cuttings, this was accomplished by using the two cultivars under evaluation. For

62 micropropagation trials, considering the recalcitrance of the cv. 'Cobrançosa' under in vitro culture

63 conditions, microshoots of the cultivar 'Galega Vulgar' were treated with salicylhydroxamic acid (SHAM).

64 SHAM has been shown to inhibit root formation in olive (Santos Macedo et al., 2012), thus providing a

65 negative control by imitating a difficult-to-root cultivar.

66

67 
IAA, IBA, SHAM, 4-methylcatechol and p-coumaric acid were purchased from Sigma-Aldrich Quimica,

71 S.A., Sintra, Portugal. Agar-agar, D-mannitol, activated charcoal, sodium acetate, 3-methyl-2-

72 benzothiazolinone-hydrazone-hydrochloride, and isopropanol were all supplied by Merck-Portugal,

73 Lisboa, Portugal. Ethylenediamine-tetra-acetic acid and magnesium chloride were purchased from VWR-

74 Portugal, Carnaxide, Portugal. Phenylmethylsulfonyl fluoride was supplied by AppliChem, Darmstadt,

75 Germany. Hydrogen peroxide was purchased from Alfa Aesar GmbH, Karlsruhe, Germany. Formic acid

76 and ammonium hydroxide were supplied by Merck S.A., Germany. Indole-3-propionic acid was

77 purchased from Sigma-Aldrich, MO, USA. $\left[{ }^{13} \mathrm{C}_{6}\right]$ IAA was supplied by Cambridge Isotopes Laboratories,

78 MA, USA. Acetone (HPLC-grade), hexane (HPLC-grade), methanol (LC/MS-grade), chloroform (HPLC-

79 grade) and sodium chloride ( $\geq 99.0 \%$ purity) were purchased from Sigma-Aldrich (St. Louis, MO, USA).

80 Butylated hydroxytoluene (BHT) was purchased from MP Biomedicals (Solon, OH, USA). Hydrochloric

81 acid ( $\mathrm{HCl}$ ) (36.5 - 38.0\% purity) was purchased from J.T. Baker (Center Valley, PA, USA). N,O-

82 bis(trimethylsilyl)trifluoroacetamide (BSTFA) for GC derivatization ( $\geq 99.0 \%$ purity) was purchased from

83 Sigma-Aldrich (St. Louis, MO, USA).

84

85

86

\subsection{Plant material, rooting procedures, and culture conditions}

87 In vitro-cultured microshoots and semi-hardwood cuttings were used as initial explants for the rooting

88 trials. In vivo trials were performed using semi-hardwood cuttings of a single clone of the olive cultivar

89 'Galega Vulgar' and a single clone of cv. 'Cobrançosa', while the in vitro experiments were achieved 90 using only a clone of the cultivar 'Galega Vulgar'. 
91 In vitro rooting experiments: Microshoots established in vitro since 2005 and maintained to date

92 according to the protocol proposed by Peixe et al. (2007). Rooting treatments and culture conditions were adapted from Macedo et al. (2013). In brief, explants with four-to-five nodes were prepared from in vitro-cultured microshoots, and all leaves, except for the upper four, were removed. The base of each explant (approx. $1.0 \mathrm{~cm}$ ) was submitted to a $10 \mathrm{~s}$ quick-dip treatment either in a sterile solution of 14.7 mM IBA or a sterile solution of 14.7 mM IBA plus 100 mM SHAM (concentration optimized by Santos Macedo et al., 2012). The explants were then inoculated, in vitro, in $500 \mathrm{ml}$ glass flasks containing $75 \mathrm{ml}$ semi-solid olive culture medium (OM), devoid of plant growth regulators and supplemented with $7 \mathrm{~g} \mathrm{~L}^{-1}$ commercial agar-agar, $30 \mathrm{~g} \mathrm{~L}^{-1} \mathrm{D}$-mannitol and $2 \mathrm{~g} \mathrm{~L}^{-1}$ activated charcoal (Rugini, 1984). Medium pH was adjusted to 5.8 prior to sterilization in an autoclave $\left(20 \mathrm{~min}\right.$ at $\left.121^{\circ} \mathrm{C}\right)$. All cultures were kept in a plant growth chamber at $24^{\circ} \mathrm{C} / 21^{\circ} \mathrm{C}\left( \pm 1^{\circ} \mathrm{C}\right)$ day/night temperatures, with a $15 \mathrm{~h}$ photoperiod, under coolwhite fluorescent lights at a photosynthetically active radiation (PAR) level of $36 \mu \mathrm{mol} \mathrm{m} \mathrm{s}^{-2}$ at culture height.

In vivo propagation: Semi-hardwood cuttings $(12-15 \mathrm{~cm}$ from the middle region of year growing sprouts) of the two cultivars under evaluation were collected from field grown plants (nursery motherplant field with 10 years after planting). To induce rooting, the base of each cutting (approx. $1.0 \mathrm{~cm}$ ) was submitted to a $10 \mathrm{~s}$ quick-dip treatment in a non-sterile solution of $17.15 \mathrm{mM}$ IBA. After IBA treatment the cuttings were transferred into a water-cooling greenhouse and planted on a rooting bench with bottom heating. The greenhouse air temperature was maintained at $22-24^{\circ} \mathrm{C}$ and the rooting substrate at $26-28^{\circ} \mathrm{C}$. Water loss through transpiration was reduced by removing all leaves except the 4 on the top and by automatically sprinkling water at regular intervals throughout the rooting assay. Relative

112 humidity was maintained at $70-80 \%$ throughout the rooting period. 


\subsection{Sample collection}

116 During in vitro rooting, ten segments from the basal portion (approx. $1 \mathrm{~cm}$ from the base) of the

117 explants were collected in triplicate at 4, 8, 24, 48, 96, 144, 192, 240, 336, 432, 528, 624 and $720 \mathrm{~h}$ after

118 auxin treatment. In addition, ten segments were collected in triplicate before auxin treatment ( 0 hours

119 after treatment) and were used as control samples. A total of 840 explants were collected. All samples

120 were flash frozen in liquid nitrogen and stored at $-80^{\circ} \mathrm{C}$ for subsequent enzyme assays.

121 Samples for auxin quantification by gas chromatography / mass spectrometry (GC/MS) were collected

122 similarly, but using double amount of explants, i.e., each sample consisted of twenty segments of plant 123 tissue, totaling 1680 explants.

124 In rooting trials with semi-hardwood cuttings a similar procedure was used for sample collection.

125 However, in this case, the sampling material consisted of a ring-bark of approximately $1 \mathrm{~cm}$-long, 126 including the bottom node of the cutting and was obtained by girdling of the cutting base.

127 These rooting trials also included control samples, taken at the time of collection from the mother plants

128 (1 hour before treatment). In total, 900 cuttings were used. Furthermore, in this case, each replicate 129 used for auxin analysis consisted in 10 segments of plant tissues.

130 A graphic representation of the experimental design used in sample collection is shown in Fig. 1. 

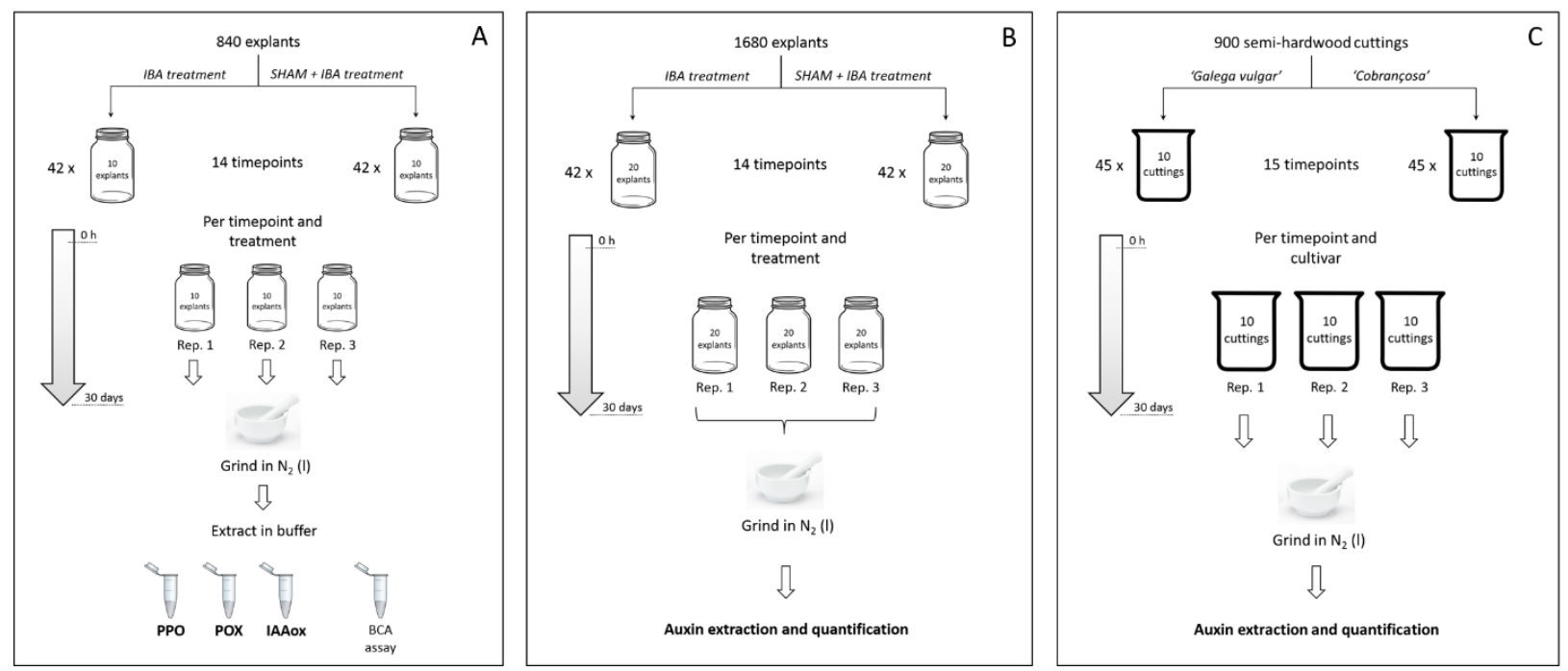

Fig. 1. Schematic representation of the experimental design used for sample collection. (A) Sample collection for enzymatic activities in microshoots; (B) Sample collection for auxin quantification in microshoots; (C) Sample collection for auxin quantification in semi-hardwood cuttings.

\subsection{Extraction of oxidative enzymes}

The collected material (ten segments per replicate per time-point) was ground and homogenized in a mortar with liquid nitrogen. Approximately $50 \mathrm{mg}$ of sample was transferred into a $1.5 \mathrm{ml}$ microtube for extraction. Samples were extracted using $1.0 \mathrm{ml}$ of extraction buffer containing $50 \mathrm{mM}$ sodium acetate, $2.0 \mathrm{mM}$ ethylenediamine-tetra-acetic acid (EDTA), $1.0 \mathrm{mM}$ magnesium chloride and $1.0 \mathrm{mM}$ phenylmethylsulfonyl fluoride (PMSF) at pH 5.5. Each extract was vigorously vortexed for $15 \mathrm{~s}$ and

142 centrifuged $(10,000 \times \mathrm{g})$ at $4^{\circ} \mathrm{C}$ for $20 \mathrm{~min}$. The supernatant was divided into 4 aliquots and used as crude 143 enzyme extract for quantification of enzyme activity (PPO, POX and IAAox) and total protein quantification. All aliquots were stored at $-80^{\circ} \mathrm{C}$ before use. 
147 Total soluble PPO and POX activities were determined based on Kar and Mishra (1976), Tzika et al. 148 (2009) and Macedo et al. (2013), with modifications.

149 PPO activity: $100 \mu \mathrm{L}$ of crude extract was added to $900 \mu \mathrm{L}$ of a buffer solution containing $45 \mathrm{mM}$ sodium 150 acetate, $2 \mathrm{mM}$ 3-methyl-2-benzothiazolinone-hydrazone-hydrochloride (MBTH) and $20 \mathrm{mM}$ 4151 methylcatechol at $\mathrm{pH}$ 5.5. Soluble PPO activity was determined by measuring the change in absorbance 152 at $490 \mathrm{~nm}$ during 1 min using a Beckman $\mathrm{DU}^{\circledR} 530$ spectrophotometer (Beckman Instruments, Inc., 153 Fullerton, CA, USA). Enzyme activity was expressed in terms of $\Delta$ Abs490 $\mathrm{min}^{-1}$ protein (mg) ${ }^{-1}$.

154 POX activity: $100 \mu \mathrm{L}$ of crude extract was added to $900 \mu \mathrm{L}$ of a buffer solution containing $45 \mathrm{mM}$ sodium 155 acetate, $2.0 \mathrm{mM} \mathrm{MBTH}, 20 \mathrm{mM}$ 4-methylcatechol and $1.0 \mathrm{mM} \mathrm{H}_{2} \mathrm{O}_{2}$ at $\mathrm{pH}$ 5.5. Soluble POX activity was 156 determined by measuring the change in absorbance at $490 \mathrm{~nm}$ during 1 min using a Beckman $\mathrm{DU}^{\circledR 5} 50$ 157 spectrophotometer (Beckman Instruments, Inc., Fullerton, CA, USA). Enzyme activity was expressed in 158 terms of $\Delta$ Abs490 $\mathrm{min}^{-1}$ protein $(\mathrm{mg})^{-1}$.

\subsection{Measurement of soluble IAA oxidase (IAAox) activity}

IAAox activity was measured using an adaptation of the methods of Güneş (2000) and Nag et al. (2001).

162 The crude extracts were incubated with a buffer containing a fixed amount of IAA and the activity of 163 IAAox was determined indirectly by measuring the remaining amount of residual IAA after the 164 incubation period.

Briefly, $100 \mu \mathrm{L}$ of crude extract was added to $650 \mu \mathrm{L}$ of a buffer solution containing $12.8 \mathrm{mM}$ sodium

166 acetate, $0.5 \mathrm{mM} \mathrm{H}_{2} \mathrm{O}_{2}, 0.1 \mathrm{mM} \mathrm{p-coumaric} \mathrm{acid} \mathrm{and} 0.1 \mathrm{mM} \mathrm{IAA}$ at $\mathrm{pH}$ 5. The mixtures were incubated at $16730^{\circ} \mathrm{C}$ for $5 \mathrm{~min}$. The reaction was stopped by adding $300 \mu \mathrm{L}$ of $n$-butanol : formic acid (15:1). A control 
Total protein concentration was determined using the bicinchoninic acid assay (BCA assay kit, Sigma-

corresponding to null activity, where the reaction was immediately stopped at 0 min incubation time by adding $n$-butanol : formic acid (15:1), was added for comparison. Samples were centrifuged at $3000 \mathrm{rpm}$ for $1 \mathrm{~min}$ and the upper organic phase was used for further quantification of IAAox activity. IAAox activity was measured indirectly through quantification of residual IAA by high performance thin layer chromatography (HPTLC).

HPTLC: The organic fractions containing residual IAA were applied in silica gel plates (LiChrospher ${ }^{\circledR} 0.2$ $\mathrm{mm}, 20 \times 10 \mathrm{~cm}$, Merck, Portugal) as $6 \mathrm{~mm}$ bands using a semi-automated device (Linomat 4, CAMAG, Muttenz, Switzerland). The plates were previously activated for $15 \mathrm{~min}$ at $70^{\circ} \mathrm{C}$. By applying known amounts of IAA standard along with the samples, a calibration curve was built in each plate to allow for IAA quantification. After $20 \mathrm{~min}$ of pre-conditioning, the plates were eluted with a mobile phase consisting of $n$-butanol : isopropanol : ammonium hydroxide : water $(2.5: 10: 1: 1, \mathrm{v} / \mathrm{v})$ in a horizontal developing chamber (CAMAG, Muttenz, Switzerland) using a solvent migration distance of $50 \mathrm{~mm}$. To remove residual ammonia completely, the plates were dried at $110^{\circ} \mathrm{C}$ on a TLC Plate Heater III (CAMAG, Muttenz, Switzerland) for $2 \mathrm{~min}$, and then cooled to room temperature. Once cooled, the plates were inspected under UV light at $254 \mathrm{~nm}$ (Dual wavelength UV lamp, CAMAG, Muttenz, Switzerland) for confirmation of IAA bands (Supplementary Figure S1). Plates were scanned (TLC Scanner 2, CAMAG, Muttenz, Switzerland) under monochromatic light in fluorescence mode and residual IAA was quantified by classical densitometry using CATS software version 3.20 /1998 (CAMAG, Muttenz, Switzerland). IAAox activity was expressed in terms of residual IAA (ng) protein $(\mathrm{mg})^{-1}$.

\subsection{Measurement of total protein content}

Aldrich Quimica, S.A., Sintra, Portugal), according to manufacturer recommendations. 


\subsection{Auxin quantification by gas chromatography/mass spectrometry (GC/MS)}

193 The collected material (twenty microshoot segments and ten semi-hardwood segments per replicate per

194 time-point) was lyophilized in preparation for auxin extraction. In the case of microshoot samples, auxin

195 extraction and quantification was performed using composite samples as a consequence of the low

196 mass of each individual replicate. Each sample was ground and homogenized in a mortar with liquid

197 nitrogen. About $100 \mathrm{mg}$ of the powdered plant tissue was transferred into a solvent-rinsed $5 \mathrm{ml}$ screw-

198 cap glass tube and extracted according to the protocol described below, using $\left[{ }^{13} \mathrm{C}_{6}\right] \mathrm{IAA}$ and IPA as

199 internal standards for IAA and IBA, respectively. The resulting methanolic extracts were further

200 submitted to dispersive liquid-liquid microextraction (DLLME) followed by microwave derivatization

201 (MAD). Finally, free IAA and IBA quantification was performed by GC/MS-SIM, as described below.

202 Briefly, $3 \mathrm{ml}$ of $80 \%$ methanol containing $1 \mathrm{mM} \mathrm{BHT}$ (stored at $4{ }^{\circ} \mathrm{C}$ before use) was added to each

203 sample to eliminate oxidation processes, and extraction was performed by end-over-end shaking in the

204 dark at $4^{\circ} \mathrm{C}$ overnight. After extraction, each tube was centrifuged (Beckman-Coulter Allegra $6 \mathrm{R}$ ) at 3000

$205 \mathrm{rpm}, 4^{\circ} \mathrm{C}$ for $10 \mathrm{~min}$ with the supernatant being transferred into a solvent rinsed conical glass tube. The

206 residual pellet was re-extracted with $1 \mathrm{ml}$ of methanol for $1 \mathrm{~h}$ under the same conditions as described

207 above. Subsequently, the extracts were combined, dried under a stream of nitrogen, redissolved with

$208420 \mu \mathrm{L}$ of methanol and diluted with water to a final volume of $3 \mathrm{ml}$. The extract was prevented from

209 being exposed to light at all stages of extraction. The samples were further purified by DLLME by adding

$2100.450 \mathrm{~g}$ of $\mathrm{NaCl}$ to the aqueous sample and adjusting the $\mathrm{pH}$ to 4 with $100 \mathrm{mM} \mathrm{HCl}$. A solvent mixture

211 containing $200 \mu \mathrm{L}$ of chloroform $\left(\mathrm{CHCl}_{3}\right)$ (extractant) and $1 \mathrm{ml}$ acetone (disperser) was injected into the

212 sample via a glass syringe forming a cloudy solution. The mixture was briefly shaken manually, sonicated

213 in ice for $1 \mathrm{~min}$ and centrifuged at $3000 \mathrm{rpm}$ for $10 \mathrm{~min}$ at $4^{\circ} \mathrm{C}$. After centrifugation, the lower organic 
214 layer was collected with a glass syringe (Hamilton, Reno, NV, USA) and transferred into a conical amber

215 GC vial (ThermoScientific, Rockwood, TN, USA). Then, the samples were subjected to MAD, using $100 \mu \mathrm{L}$ 216 of BSTFA and by heating the tightly capped vials at 630 watts (W) for 5 min in a commercially available 217 microwave oven (Hamilton Beach P70B20AP-G5W). After cooling, excess reagent was evaporated under 218 a mild stream of $\mathrm{N}_{2}$ and, immediately after drying, the derivatized samples were dissolved with $100 \mu \mathrm{L}$ 219 hexane for subsequent GC/MS analysis.

Samples were analyzed using a 7890A GC system interfaced to a 5975C MSD quadrupole spectrometer

221 (Agilent Technologies, Wilmington, DE, USA), which was equipped with an electron impact (EI) ionization 222 source. The GC was equipped with a 7693 autosampler (Agilent Technologies, Wilmington, DE, USA) and 223 the analysis was performed by a ZB-1 capillary column (Phenomenex, $30 \mathrm{~m} \times 0.250 \mathrm{~mm}$ with $0.25 \mu \mathrm{m}$ 224 film thickness df). The injected volume was set at $2 \mu \mathrm{L}$ in splitless mode for 1 minute. The front inlet 225 injector temperature was $250^{\circ} \mathrm{C}$, and the transfer line temperature was $280^{\circ} \mathrm{C}$. The ion source 226 temperature was set at $250^{\circ} \mathrm{C}$. The oven conditions used were the following: initial temperature of $80^{\circ} \mathrm{C}$ 227 held for $2 \mathrm{~min}$, temperature was ramped to $140^{\circ} \mathrm{C}$ at $20^{\circ} \mathrm{C} / \mathrm{min}$ and held for $2 \mathrm{~min}$, temperature was 228 ramped to $200^{\circ} \mathrm{C}$ at $2^{\circ} \mathrm{C} / \mathrm{min}$ and held for $5 \mathrm{~min}$ and finally, temperature was ramped to $250^{\circ} \mathrm{C}$ at $22930^{\circ} \mathrm{C} / \mathrm{min}$ and held for $10 \mathrm{~min}$. A post-run at $270^{\circ} \mathrm{C}$ for $5 \mathrm{~min}$ was included to completely clean the 230 column. Helium was the carrier gas flowing at $1 \mathrm{ml} / \mathrm{min}$. Samples were analyzed both in full scan and 231 selected ion monitoring (SIM) modes.

\subsection{Statistical analysis}

234 Temporal changes in enzyme activities and in auxin levels of semi-hardwood cuttings were analyzed by one-way ANOVA followed by post-hoc Tukey HSD test. Significant differences were considered at $p<$ 
237 between treatments and between cultivars at specific time-points were analyzed by Student's $t$-tests.

238 Significant differences were considered at $p<0.05(*), p<0.01\left({ }^{* *}\right)$ and $p<0.001\left({ }^{* *}\right)$. All analyses

239 were performed using R Studio software package (version 0.98.1083).

240

241 3. Results

\section{3.1. Rooting performance of microshoots and semi-hardwood cuttings}

243 As expected, during in vitro culture trials IBA treatment promoted rooting of olive microshoots, whereas

244 SHAM had an inhibitory effect on the formation of adventitious roots (Fig. 2). Nevertheless, no visual

245 negative traits were observed on growth and nutritional status of the microshoots treated with SHAM

246 (Fig. 2A and 2B). SHAM also had no effect on calli formation (Fig. 2C), considering that root development

247 was preceded in all microshoots by calli formation at the site of treatment. The inhibitory effect of

248 SHAM in adventitious root formation of olive microshoots was described in terms of rooting percentage

249 and number of roots per microshoot. Microshoots treated only with IBA yielded significantly higher

250 rooting rates and average number of roots per plant than microshoots treated with SHAM + IBA (Fig. 2D

251 and 2E). 

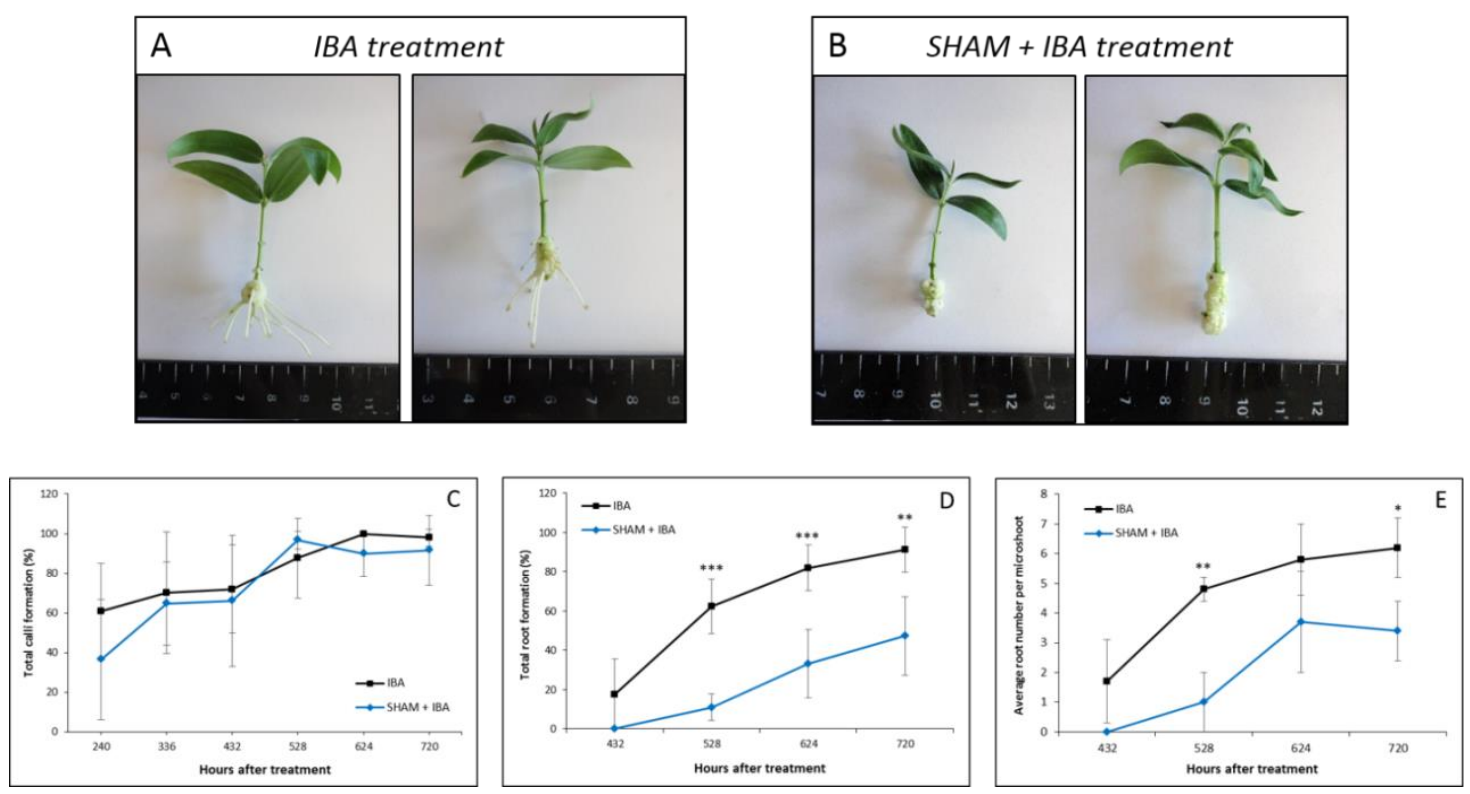

Fig. 2. Inhibitory effect of SHAM on adventitious root formation in olive microshoots. (A) Microshoots collected 30 days after treatment with $14.7 \mathrm{mM}$ IBA; (B) Microshoots collected 30 days after treatment with $14.7 \mathrm{mM} \mathrm{IBA}+$ 100 mM SHAM; (C) Effect of SHAM on calli formation; (D) Effect of SHAM of rooting percentage; (E) Effect of SHAM on number of roots per microshoot. $\left({ }^{*} p<0.05 ;{ }^{* *} p<0.01 ;{ }^{* *} p<0.001\right)$

Data from trials performed with semi-hardwood cuttings of the two selected olive cultivars confirmed their characteristic rooting performance 60 days after treatment: 'Galega Vulgar' showed 4\% of rooted cuttings (difficult-to-root) and 'Cobrançosa' presented $60 \%$ of rooted cuttings (easy-to-root). The experiments were performed in winter, usually the worst period of the year for rooting, aiming to observe the maximal expression of the cultivars features regarding adventitious root formation. 
The activities of several oxidative enzymes were evaluated during adventitious rooting. Although a similar pattern was observed in microshoots treated only with IBA and those treated with SHAM + IBA

\section{(Fig. 4).}
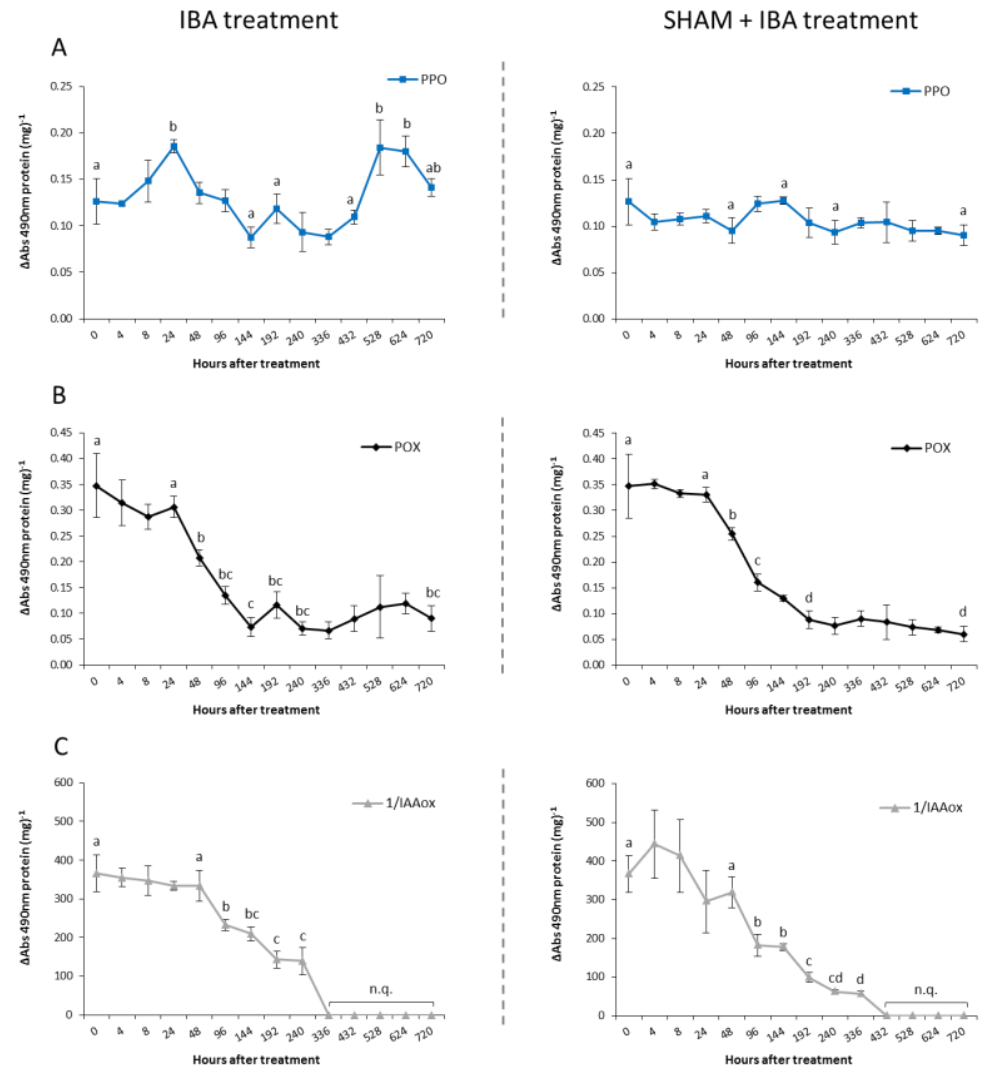

Fig. 3. Effect of SHAM treatment on activity levels of oxidative enzymes during adventitious root formation in olive microshoots. Activity levels of PPO (A), POX (B) and IAAox (C) were measured on microshoots treated with

273 IBA (left) and SHAM + IBA (right). Different lower-case letters correspond to statistically significant differences $(p<$ $2740.05)$.

276 In microshoots treated only with IBA (Fig. 3), PPO activity varied significantly throughout adventitious 277 root formation. Thus, such activity increased initially up to a maximum at $24 \mathrm{~h}$, then proceeded to a 
278 minimum at $144 \mathrm{~h}$, that was followed by a new significant increase (68\%) at $528 \mathrm{~h}$. POX activity 279 decreased significantly until $144 \mathrm{~h}$, increased until $192 \mathrm{~h}$ and decreased again at $240 \mathrm{~h}$, maintaining a 280 somewhat constant level until 720 h. IAAox activity was nearly constant during the first $48 \mathrm{~h}$ of 281 induction. Then, it showed a significant increase (30\%) at $96 \mathrm{~h}$ and increased to a maximum thereafter. 282 At $336 \mathrm{~h}$ and onwards, no residual IAA was detected, indicating very high IAAox activity levels.

283 On the other hand, microshoots treated with SHAM + IBA (Fig. 3), showed a nearly constant PPO activity 284 throughout root formation. In this case POX activity also decreased significantly during root formation, 285 at a more constant pace than in IBA treatment and it stabilized after $192 \mathrm{~h}$. IAAox activity also increased 286 throughout adventitious rooting. Whereas such an increase was not significant until $48 \mathrm{~h}$, two significant 287 increases were observed at $96 \mathrm{~h}$ and $192 \mathrm{~h}$. Finally, the maximum IAAox activity was reached at $432 \mathrm{~h}$ (no 288 detectable residual IAA), exactly 96 hours later than in IBA treatment, remaining stable until the end of 289 the trial, at $720 \mathrm{~h}$.

290 Differences were observed between treatments regarding each enzyme activity (Fig. 4). PPO activity 291 levels were typically higher in microshoots treated only with IBA, except at $144 \mathrm{~h}$ when this trend was 292 reversed. Indeed, significant differences between treatments were identified at 8, 24, 48, 144, 528,624 293 and $720 \mathrm{~h}$ (Fig. 4A). On the contrary, differences between treatments in terms of POX and IAAox 294 activities were less identified. In the case of POX activity, significant differences were only found at 48, 295144 and $624 \mathrm{~h}$. While at 48 and $144 \mathrm{~h}$ activity levels were significantly higher in microshoots treated with 296 SHAM + IBA, microshoots treated with IBA had higher POX activity at $624 \mathrm{~h}$ (Fig. 4B). Significantly higher 297 IAAox activity was also found in SHAM + IBA microshoots at 96, 192 and $240 \mathrm{~h}$ (Fig. 4C). 

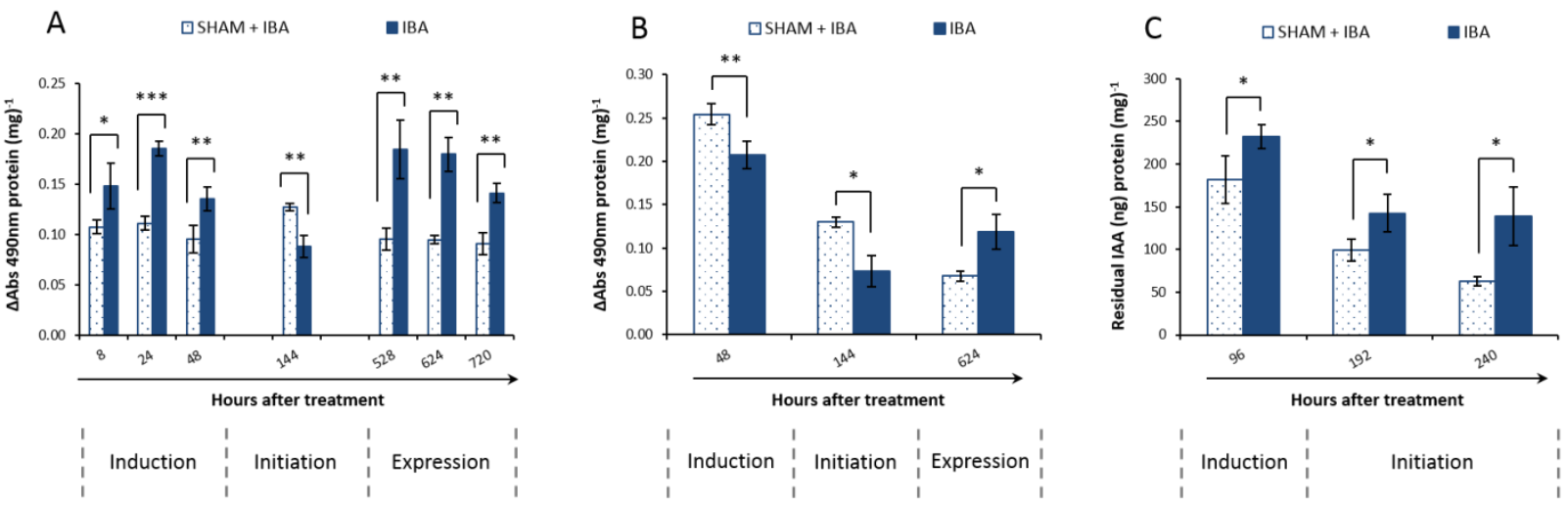

Fig. 4. Effect of SHAM treatment on individual enzyme activities. (A) PPO activity, (B) POX activity, (C) IAAox activity $(* p<0.05 ; * * p<0.01 ; * * * p<0.001)$. The indicated rooting stages were previously determined by Macedo et al. (2013). The timepoints shown here do not indicate the length of each phase.

\subsection{Evaluation of free auxin levels}

\subsubsection{Free auxin levels in microshoots}

Temporal changes in free IAA and IBA were evaluated throughout adventitious root formation in

307 microshoots treated with IBA and with SHAM + IBA (Fig. 5). In both treatments, auxin levels increased 308 drastically in the first hours after treatment and tended to decrease with time. Concerning IBA-treated microshoots, IAA levels reached a peak at $8 \mathrm{~h}$, decreased significantly to a plateau between 24 and $48 \mathrm{~h}$ and decreased again until the end of the rooting period (Fig. 5A). In turn, IBA levels showed a similar trend although not so linear: they reached a peak earlier than IAA levels (at $4 \mathrm{~h}$ ), decreased until $24 \mathrm{~h}$ and then increased again at $48 \mathrm{~h}$. After this lower increase, IBA levels decreased until $96 \mathrm{~h}$ and a new increase was observed between 96 and $192 \mathrm{~h}$. From this point onwards IBA levels decreased significantly to a minimum at $720 \mathrm{~h}$ (Fig. 5B). A similar trend was observed for IBA levels in microshoots treated with SHAM + IBA (Fig. 5D). In contrast, IAA levels in these microshoots showed a very different pattern than 
in microshoots treated with IBA alone. In SHAM + IBA treatment, IAA levels also reached a peak at $8 \mathrm{~h}$

317 and decreased markedly at $24 \mathrm{~h}$, but increased again significantly (247\%) at $48 \mathrm{~h}$ to a level close to that of $4 \mathrm{~h}$, decreasing after this point until the end of the rooting assay (Fig. $\mathbf{5 C}$ ).
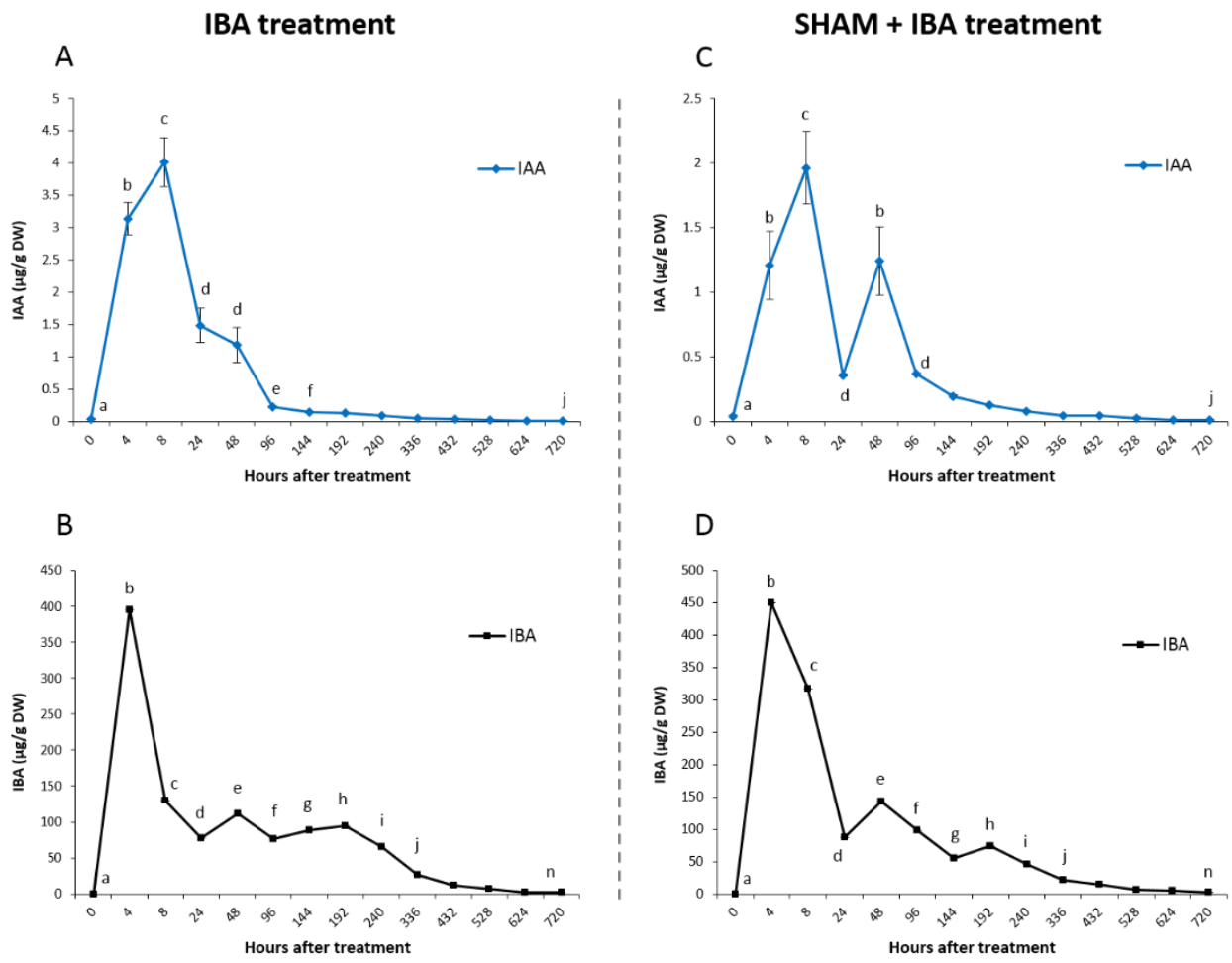

Fig. 5. Changes in free auxin levels during adventitious root formation in olive microshoots treated with IBA

(left) and with SHAM + IBA (right). (A) IAA levels in microshoots treated with IBA; (B) IBA levels in microshoots treated with IBA; (C) IAA levels in microshoots treated with SHAM + IBA; (D) IBA levels in microshoots treated with SHAM + IBA. Different lower-case letters correspond to statistically significant differences $(p<0.05)$. with IBA, while IAA levels were consistently higher, the reverse was observed for IBA levels, at least during the first stages of root formation. During the first 24h, IAA levels in IBA-treated shoots were $100-$ $200 \%$ higher than IAA levels in shoots treated with SHAM + IBA (a representative chromatogram is 
shown in Supplementary Fig. S2). However, at $48 \mathrm{~h}$ this difference was no longer observed, as a result of

330 a marked increase of IAA levels in SHAM + IBA treatment. Actually, at 96 and $144 \mathrm{~h}$ IAA levels were

331 significantly higher in SHAM + IBA microshoots (Fig. 6A). After this point no differences were observed

332 between treatments in terms of IAA levels. By contrast, IBA levels were significantly higher in SHAM +

333 IBA microshoots until $96 \mathrm{~h}$, especially at $8 \mathrm{~h}(317 \pm 6 \mu \mathrm{g} / \mathrm{g}$ compared with $130 \pm 1 \mu \mathrm{g} / \mathrm{g})$. From 144 to 240

$334 \mathrm{~h}$ this trend was reversed and from 336 to $720 \mathrm{~h}$ IBA levels decreased progressively to a minimum in

335 both treatments (Fig. 6B).

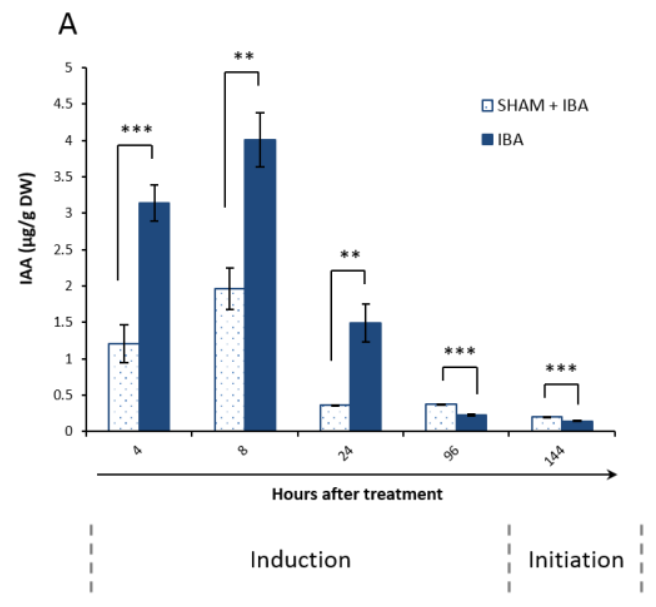

Fig. 6. Effect of SHAM treatment in free IAA (A) and free IBA (B) levels during adventitious root formation in olive microshoots. $\left({ }^{* *} p<0.01 ;{ }^{* * *} p\right.$ $<0.001)$ The indicated rooting stages were previously determined by Macedo et al. (2013).

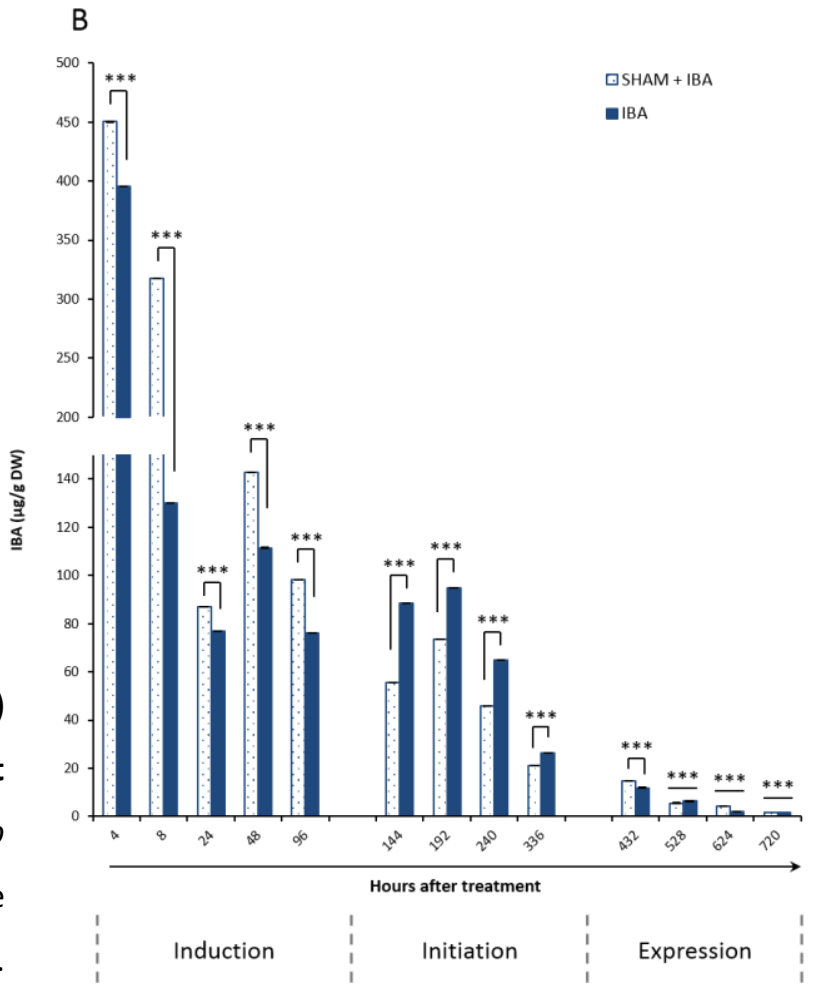
The timepoints shown here do not indicate the length of each phase. 
341 Changes in free IAA and IBA levels were evaluated over the rooting period (Fig. 7 and Fig. 8). In 'Galega

342 Vulgar' cuttings, IAA levels tended to increase significantly during the first $24 \mathrm{~h}$, decreased to a transient

343 minimum at $48 \mathrm{~h}$ and increased again to a peak at $144 \mathrm{~h}$. After this point, IAA levels decreased to a

344 minimum at $192 \mathrm{~h}$ and remained relatively constant until $624 \mathrm{~h}$, when a new increase was observed up

345 to $720 \mathrm{~h}$ (Fig. 7A). Contrarily, in 'Cobrançosa' cuttings, IAA levels increased to a maximum at $24 \mathrm{~h}$ and 346 decreased steeply at $48 \mathrm{~h}$, continuing to decrease until $192 \mathrm{~h}$. Between $240 \mathrm{~h}$ and $720 \mathrm{~h}$ IAA levels

347 increased significantly, reaching a new peak at $528 \mathrm{~h}$ (Fig. 7C).

348 IBA levels described a peak at $4 \mathrm{~h}$ in both cultivars, decreasing sharply until $48 \mathrm{~h}$. After this point, in 349 'Galega Vulgar' levels remained low until 624 h, increasing significantly until 720 h (Fig. 7B). In turn, in 350 'Cobrançosa' cuttings three statistically significant transient peaks were observed at 96, 336 and $528 \mathrm{~h}$, 351 and IBA levels decreased after this point (Fig. 7D).

‘Galega vulgar' (4 \% rooting)
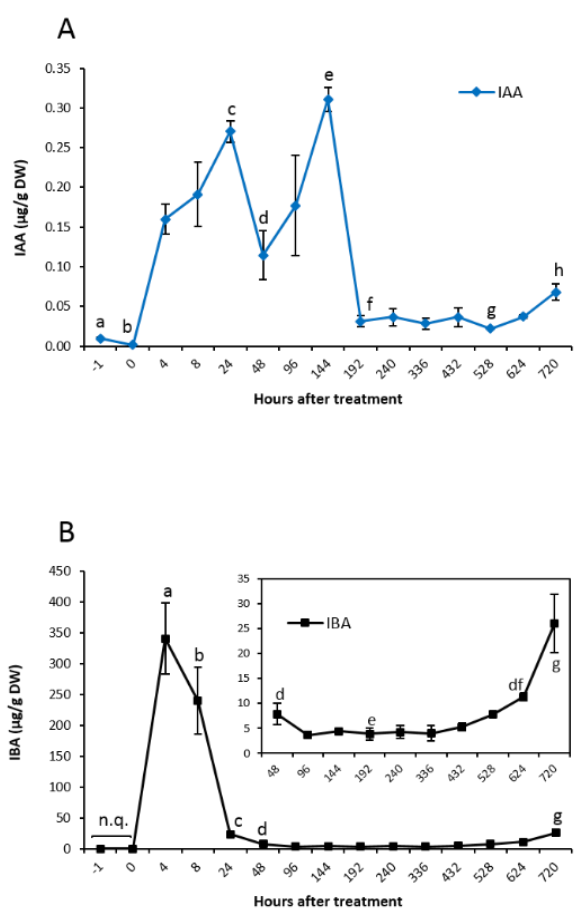
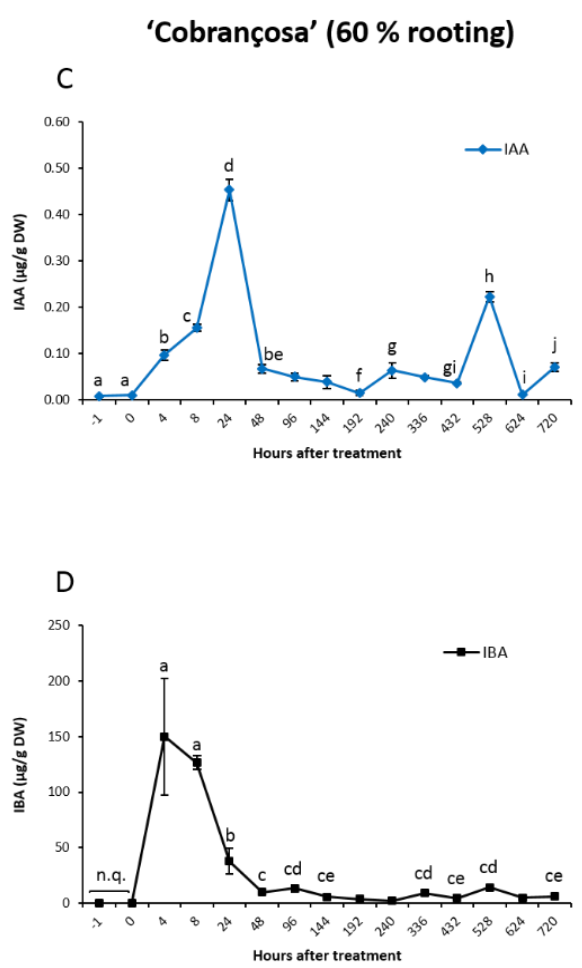
Fig. 7. Changes in free IAA and IBA levels during rooting of semi-hardwood cuttings. (A) IAA levels of 'Galega Vulgar' cuttings; (B) IBA levels of 'Galega Vulgar' cuttings; (C) IAA levels of 'Cobrançosa' cuttings; (D) IBA levels of 'Cobrançosa' cuttings. Different lower-case letters correspond to statistically significant differences $(p<0.05)$. n.q. $=$ not quantified.

Several differences in auxin levels were found between cultivars. IAA levels were significantly higher in 'Galega Vulgar' cuttings in early induction phase and also during initiation. Conversely, IAA levels were higher in 'Cobrançosa' cuttings during late induction and expression phases (Fig. 8A). In contrast, IBA levels were higher in 'Galega Vulgar' cuttings during induction phase (4-8 h) while 'Cobrançosa' cuttings had equal or higher IBA levels than 'Galega Vulgar' cuttings during initiation and early

8B).

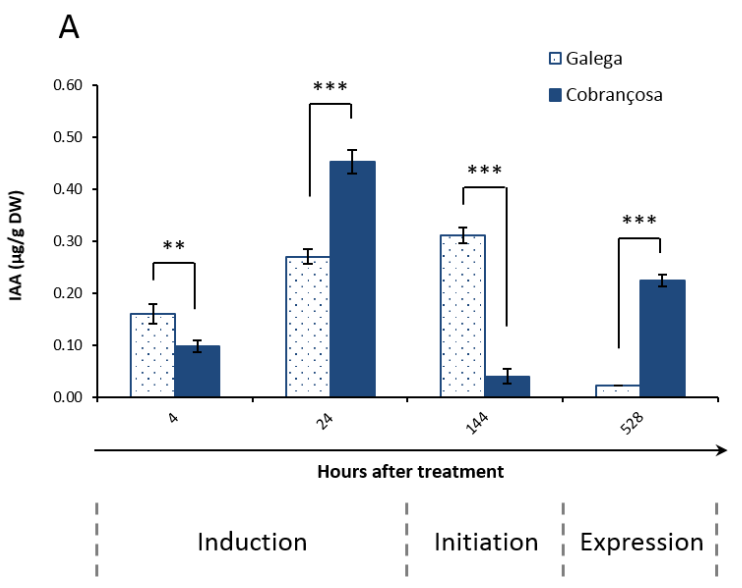

Fig. 8. Levels of free IAA (A) and IBA (B) in the two evaluated olive cultivars $\left({ }^{*} p<0.05 ;{ }^{* *} p<0.01\right.$; ${ }^{* * *}$ $p<0.001)$ The indicated rooting stages were previously determined by Macedo et al. (2013). The timepoints shown here do not indicate the length of B

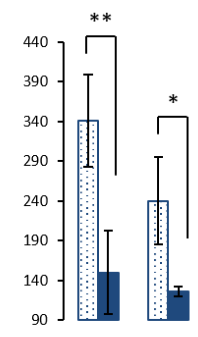

๑Galega

- Cobrancosa

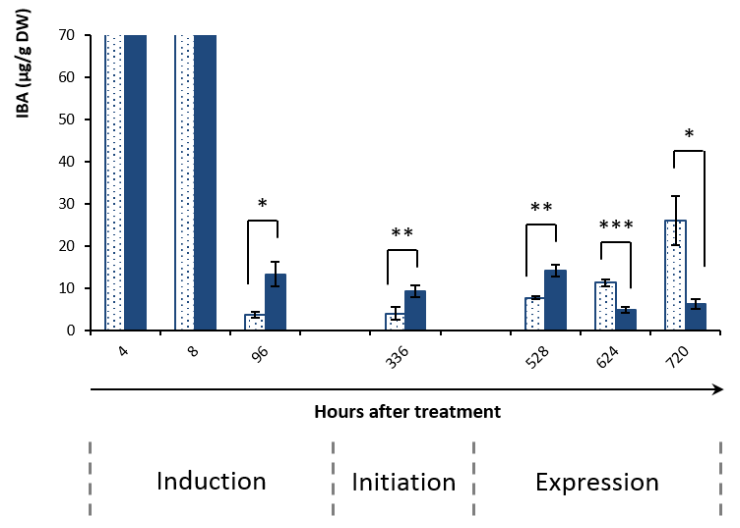
each phase. 


\section{Discussion}

\subsection{Rooting performance as affected by treatments and cultivars}

370 Confirming previous results on this subject (Santos Macedo et al., 2009, 2012), the treatment of olive

371 microshoots with SHAM significantly reduced the rooting percentage and the average number of roots

372 per microshoot, therefore inhibiting the formation of adventitious roots. Also in agreement with 373 previous results obtained in olive (Santos Macedo et al., 2009, 2012), the inhibitory effects of SHAM did 374 not affect calli percentage because in both treatments, calli formation always preceded root 375 development at the site of treatment. These results suggest the inhibitory effect of SHAM is likely 376 related with the later stages of adventitious root induction rather than with cell dedifferentiation. SHAM

377 has been suggested to suppress adventitious rooting in olive by inhibiting AOX activity (Santos Macedo 378 et al., 2009, 2012), which could lead to an increased production of reactive oxygen species (ROS), as 379 documented for tobacco, soybean and pea (Maxwell et al., 1999; Popov et al., 1997; Van Aken et al., 380 2009). However the exact action of SHAM in adventitious rooting is not well understood and other 381 molecular mechanisms may be involved in the process, as discussed below.

\subsection{Temporal changes in oxidative enzymes activity}

384 Monophenols, such as SHAM, have been reported to stimulate the enzymatic degradation of IAA by 385 IAAox in vitro as well as in maize stems (Grambow and Langenbeck-Schwich, 1983; Lee, 1980) and this 386 effect is dependent on the type of monophenol. $p$-substituted monophenols (as the case of $p$-coumaric 387 acid, used here in the determination of IAAox activity) are described to be more active in IAAox 388 stimulation than $m$ - and $o$-monophenols (Lee, 1980). Although the mechanism controlling this effect 
hasn't been clarified, phenolic co-factors may act as electron donors allowing recycling of the Fe ${ }^{3+}-\mathrm{IAAox}$

390 isoform during IAA degradation (Pedreño et al., 1990). Therefore, $m$-monophenols like SHAM could possibly promote enzymatic IAA catabolism by IAAox, leaving less free IAA available for root formation and ultimately inhibiting rooting. Indeed, we observed that microshoots treated with SHAM + IBA had significantly lower amounts of residual IAA, indicative of a higher IAAox activity, during initiation (at 96, 192 and 240 h). Similar results were found in Populus sp., where recalcitrant cuttings had higher IAAox activity throughout the rooting process and IAAox activity reached its peak during root emergence (Güneş, 2000). On the other hand, IAAox activity increased faster in IBA-treated microshoots: at $336 \mathrm{~h}$ no residual IAA was detected while in SHAM+IBA-treated microshoots this only happened at $432 \mathrm{~h}$. This could indicate higher levels of IAA during expression phase, which have been described to be detrimental to root formation in apple microcuttings (De Klerk et al., 1995), hindering or delaying the rooting process in SHAM+IBA-treated explants.

IAAox are described as a group of POX isoforms responsible for the enzymatic, $\mathrm{H}_{2} \mathrm{O}_{2}$-dependent, oxidative degradation of IAA (Ljung et al., 2002). POX are also responsible for the oxidation of many other phenolic compounds, such as lignin precursors (Hiraga et al., 2001). During root induction and early initiation (Macedo et al., 2013), difficult-to-root microshoots treated with SHAM + IBA showed higher POX activity, in agreement with results from Güneş (2000), Faivre-Rampant et al. $(1998,2000)$ and Ludwig-Müller (2003). Considering that total POX activity was measured in this work, this result is

407 likely related with the increased IAAox activity observed also in SHAM+IBA-treated microshoots. POX are 408 described to have an extremely high isozymic variety (Siegel, 1993), which is reflected in a broad 409 diversity of functions (Passardi et al., 2005). In fact, several reports described changes in the number of 410 POX isoforms during rooting of peach rootstock GF-677, Nothofagus sp., Ebenus cretica and Vitis vinifera

411 (Molassiotis et al., 2004; Pastur et al., 2001; Syros et al., 2004; Vatulescu et al., 2004). Therefore, total 412 POX activity may decrease during rooting, although specific isoforms, such as IAAox, increase their 
413 activity to control IAA levels and facilitate the development of new adventitious roots by stimulating

414 lignin formation and cross-linking of cell wall components (Passardi et al., 2004, 2005). This would also

415 explain why IBA-treated explants have higher POX activity during expression phase, since more roots are

416 produced in response to this treatment, in agreement with Tonon et al. (2001). A decrease in POX

417 activity during root formation, also described by Tartoura et al. (2004) and Fekete et al. (2002), could be

418 a result of the root-inducing treatment itself. IBA treatments significantly decreased POX activity in

419 mung bean seedlings (Li et al., 2009b) and naphtaleneacetic acid (NAA) has been described to have a

420 suppressive effect on POX gene expression in soybean hypocotyls (Chen et al., 2002). This suppressive

421 effect could be a results of auxin responsive elements that are regulated by exogenously applied auxins,

422 as suggested by results from Cinnamomum kanehirae (Cho et al., 2011).

423 A reversed behavior between POX and IAAox has already been reported in Zea mays (Beffa et al., 1990)

424 and Populus tomentosa (Jinyao et al., 2001). After chromatographic purification of maize extracts, Beffa

425 et al. (1990) described that fractions containing a high IAAox activity showed a low POX activity and vice

426 versa. Higher POX activity has also been related with lower rooting ability in Arbutus unedo, Taxus

427 baccata and peach rootstock GF-677 (Metaxas et al., 2004; Molassiotis et al., 2004). Furthermore, SHAM

428 can act as a substrate for some POX (Gumiero et al., 2010), which would also contribute to higher POX

429 activity in SHAM+IBA-treated microshoots. Unlike previous reports from other species such as Casuarina

430 equisetifolia and Asparagus sp. (Gaspar et al., 1992; Rout et al., 1996), a clear relationship between POX

431 activity and rooting ability couldn't be established from our results, which had already been described

432 by other authors (Güneş, 2000). Nevertheless, the results presented here confirm previous work also

433 describing a significant decrease in POX activity in the first $24 \mathrm{~h}$ after IBA treatment, a period included in

434 the induction phase in olive (Macedo et al., 2013). 
435 The biggest changes in enzyme activity were observed in PPO activity. While in SHAM+IBA-treated 436 microshoots no major changes were detected during root formation, in IBA-treated explants PPO 437 activity significantly increased during induction, decreased during initiation and increased again during 438 expression. These results are in agreement with results from Qaddoury and Amssa (2003), Satisha et al. 439 (2008) and Cheniany et al. (2010), who observed a larger magnitude of changes in PPO activity in easy440 to-root cultivars of Phoenix dactylifera, Vitis sp. and Juglans regia. Sharp increases of PPO activity and 441 higher PPO activity have also been related with enhanced rooting in other species (Bruguiera parviflora, 442 Cynometra iripa, Excoecaria agallocha, Heritiera fomes, Thespesia populnea, Eucalyptus urophylla) 443 (Basak et al., 2000; Li et al., 1999). The increased PPO activity during rooting, previously described in 444 olive (Macedo et al., 2013), could be associated with lignification processes and/or phenolic metabolism 445 (Batish et al., 2008), or could be related to $\mathrm{H}_{2} \mathrm{O}_{2}$ levels. $\mathrm{H}_{2} \mathrm{O}_{2}$ has been suggested to work as signaling 446 molecule, acting downstream in the auxin signaling pathway, mediating auxin responses prior to 447 adventitious rooting in cucumber ( $\mathrm{Li}$ et al., 2007, 2009a). Li et al. (2009c) reported an increase in 448 endogenous $\mathrm{H}_{2} \mathrm{O}_{2}$ levels in mung bean seedlings after IBA treatment and removal of the primary root, 449 suggesting that IBA may induce rooting indirectly through a pathway involving $\mathrm{H}_{2} \mathrm{O}_{2}$. Further evidence 450 showed that $\mathrm{H}_{2} \mathrm{O}_{2}$ treatments, which enhanced adventitious rooting, stimulated PPO activity in 451 Chrysanthemum (Liao et al., 2010), possibly through activation of AOX (Santos Macedo et al., 2009). IBA 452 treatments promote AOX gene transcription in olive (Santos Macedo et al., 2012), which in turn can 453 stimulate phenylpropanoid biosynthesis (Sircar et al., 2012; Vogt, 2010) leading to an increased 454 concentration of monophenolic compounds, which are natural substrates of PPO. This would also 455 explain why in microshoots treated with SHAM, an AOX inhibitor, no visible changes in PPO were 456 detected. Alternatively, auxin could promote the apoplastic production of ROS that increase cell wall 457 extensibility by promoting the breakdown of polysaccharides and proteins (Schopfer et al., 2002). In 458 response to the increased generation of ROS, the plant could produce more phenolic compounds with 
antioxidant properties to control the oxidative burst and the accumulation of these PPO substrates

460 would then stimulate an increase in PPO activity.

\subsection{Temporal changes in free auxin levels}

Significant fluctuations in IAA and IBA levels were found throughout adventitious rooting in explants treated with IBA and with SHAM + IBA. As a result of the root inducing treatment, free IBA levels increased steeply during the first $4 \mathrm{~h}$ in both treatments suggesting that the inhibitory effect of SHAM is not related with IBA. In fact, IBA levels in microshoots treated with SHAM + IBA were higher than in

467 microshoots treated with IBA alone. Also in both treatments, IBA levels decreased significantly at $24 \mathrm{~h}$ 468 and increased again up to a transient peak at $48 \mathrm{~h}$. During this period, IAA levels had a similar increase in the first hours after treatment, peaking at $8 \mathrm{~h}$. This delay in the peak of auxin levels points to a 470 conversion of IBA into IAA, as described to happen in olive (Epstein and Lavee, 1984) and other species 471 such as Arabidopsis (Ludwig-Müller et al., 2005; Strader et al., 2011). Thus, as proposed by some authors

472 (Korasick et al., 2013; Strader and Bartel, 2011), the root inducing effect of IBA treatments is likely to 473 happen indirectly through an increase in IAA levels during induction phase, which has been described to 474 be a requirement for successful adventitious root formation in apple microcutings (De Klerk et al., 1995). 475 However, the high IAA concentrations essential for induction phase, become inhibitory during initiation. 476 Interestingly, higher IAA levels were found in IBA-treated microshoots during induction but not during 477 early initiation: actually at 96 and $144 \mathrm{~h}$ IAA levels were higher in SHAM+IBA-treated microshoots. 478 Moreover, in IBA-treated microshoots, IAA levels decreased progressively after $8 \mathrm{~h}$ until the end of the 479 rooting period, while in explants treated with SHAM + IBA a notorious peak was observed at $48 \mathrm{~h}$. 480 Furthermore, SHAM-treated microshoots had higher IBA levels, yet lower IAA levels, than IBA-treated 481 explants. All these results suggest that root inhibition by SHAM + IBA treatment is partly caused by 
excessive auxin levels, in agreement with De Klerk et al. (1995). Curiously, in contrast to IAA levels, IBA

483 levels were lower in SHAM+IBA-treated microshoots during initiation phase, which may indicate that a

484 defective IBA-IAA conversion could also be one of the causes for rooting impairments in these explants.

485 The temporal changes of IAA levels also correspond to changes in IAAox activity, as an inverse 486 relationship between IAAox activity and IAA levels was found. IAAox activity was lower during induction

487 (when IAA levels were higher) and increased thereafter reaching a maximum during expression phase, 488 when IAA levels decreased to a minimum. Although the changes in IAA levels observed in SHAM+IBAtreated microshoots did not perfectly correspond to changes in IAAox, the possibility of IAA conjugates controlling auxin levels cannot be excluded. In fact, Tartoura et al. (2004) showed that the levels of 491 conjugated IAA have a reverse trend to those of free IAA levels, increasing during expression phase 492 when free IAA levels decrease to a minimum. These authors actually suggest that conjugates, rather 493 than IAAox, are responsible for regulating IAA levels during the primary stages of adventitious rooting of 494 Vigna radiata cuttings. Indeed auxin conjugates have a key role in the regulation of auxin levels 495 (reviewed in Korasick et al. (2013); Ludwig-Müller, 2011). Consequently, it must be considered the 496 possibility that SHAM+IBA-treated microshoots may have different levels of conjugated IAA and/or IBA 497 and that this affects IAA levels more than IAAox activity. Surely, quantification of conjugated auxin levels would definitely help clarifying this matter and it is an important area of future work.

\subsection{Relationship between data from microshoots and semi-hardwood cuttings}

501 Several similarities were found between the results obtained with in vitro-cultured microshoots and 502 those obtained with semi-hardwood cuttings. In semi-hardwood cuttings, free IAA and IBA levels also 503 increased during the first hours after IBA treatment, likely as a result of auxin absorption by the cuttings. 504 A peak of free IAA was observed at $144 \mathrm{~h}$ during initiation and this peak was even higher than the one at 
$24 \mathrm{~h}$ during induction. This resembles the evolution of IAA levels in SHAM+IBA-treated microshoots,

506 where rooting was also inhibited. On the contrary, IAA levels in 'Cobrançosa' cuttings increased to a 507 peak at $24 \mathrm{~h}$ and decreased during initiation phase, resembling microshoots treated with IBA alone 508 which displayed high rooting rates. Similarly, IBA levels were higher in 'Galega Vulgar' during induction 509 and lower during initiation, a pattern also observed between IBA and SHAM + IBA treatments. 510 Moreover, at $528 \mathrm{~h}$ a peak in auxin levels was found in 'Cobrançosa' cuttings but not in 'Galega Vulgar' 511 cuttings. However, the meaning of this peak is currently unknown.

\section{Conclusions}

514 To the best of our knowledge, this was the first attempt to evaluate the molecular mechanisms involved on the adventitious root formation process in 0 . europaea. In fact, whereas the role of oxidative enzymes and auxins is broadly described in the literature, the results tend to be species- or genotypedependent and studies approaching this subject in olive are scarce.

518 Although further work is needed to help explaining the precise mechanisms involved in adventitious root formation, especially by integrating knowledge on its molecular basis with its genetic control, the

520 data presented and its interpretation seem to allow proposing an integrated perspective of the

521 molecular pathways which may putatively regulate the process in olive (Fig. 9). Root-inducing 522 treatments commonly used in propagation procedures are usually based on the exogenous application 523 of auxins such as IBA (IBA exo ), which have been proposed to promote AOX gene transcription (Santos 524 Macedo et al., 2012). The resulting increase in AOX activity may lead to two consecutive metabolic 525 consequences: i) indirect stimulation of the biosynthesis of phenylpropanoids (Sircar et al., 2012), many 526 of which derivatives are substrates of PPO and/or POX, and ii) direct decrease of $\mathrm{H}_{2} \mathrm{O}_{2}$ levels which may 527 negatively affect POX activity at substrate level, allowing phenylpropanoids to be more available for 
528 other metabolic pathways such as accumulation of monophenolics. This would facilitate PPO action and

529 the consequent polymerization of the resulting products. Resulting polymers, such as precursors of 530 lignin (which is necessary for cell wall synthesis and expansion) (Hiraga et al., 2001; Vanholme et al., 5312010 ) are susceptible to be metabolized by POX enzymes, which could ultimately act on these substrates 532 once $\mathrm{H}_{2} \mathrm{O}_{2}$ levels rebound after the initial AOX activity decreases, at the end of induction or early 533 initiation. Moreover, IAA degradation by IAAox during this phase, also generates ROS (Schopfer et al., 534 2002), which may stimulate the production of antioxidant phenolic compounds, also increasing PPO 535 activity.

536 On the other hand, exogenously applied IBA can be directly converted into free IAA (Epstein and Lavee, 537 1984), which can then be conjugated with sugars or aminoacids for storage (Ludwig-Müller, 2011). Our 538 results indicate that differences in conversion and/or conjugation of IBA and IAA may explain different 539 rooting behaviors.

540 Finally, SHAM may inhibit adventitious rooting in different ways: i) as a POX substrate (Gumiero et al., 541 2010), increasing the activity of these enzymes; ii) stimulating IAA degradation by enhancing IAAox 542 activity (Lee, 1980); or iii) inhibiting AOX during induction phase, as proposed by Santos Macedo et al. $543(2009,2012)$. Comprehending the exact role of SHAM, as well as evaluating the changes in conjugated 544 auxins during adventitious rooting are fundamental pieces of information necessary to complete this 545 puzzling subject. 


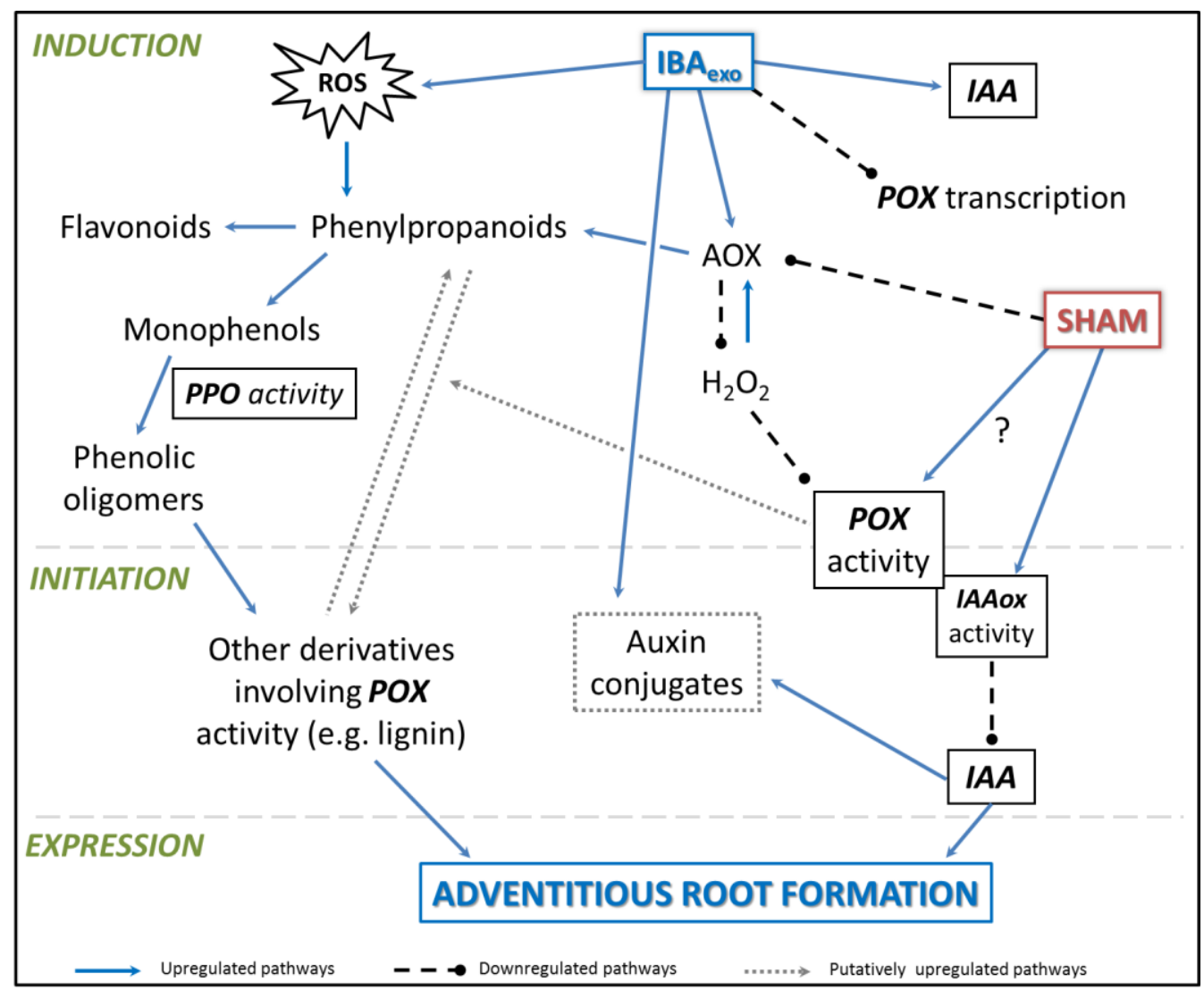

Fig. 9. Schematic representation of molecular pathways putatively involved in olive adventitious root formation.

548 It was also possible to infer from data analysis that SHAM treatments in in vitro cultured microshoots

549 can imitate a difficult-to-root cultivar and thus provide a negative control for comparative studies on

550 adventitious root formation of olive cuttings. Bearing in mind that studies involving semi-hardwood

551 cuttings are currently detrimental, considering the highly random response associated with this type of

552 plant material, in vitro studies can be performed instead, to compensate for this high variability.

Authors acknowledge funding from the Portuguese Foundation for Science and Technology (FCT),

556 through the projects PTDC/AGR - AM/103377/2008 and PEst-C/AGR/UI0115/2011, through the 
through the Doctoral grant SFRH/BD/80513/2011. Authors also acknowledge funding from FEDER funds

through the Competitiveness Factors Operational Program (COMPETE) and from the American

United States.

\section{References}

Ayoub, S., Qrunfleh, M.M., 2008. A study on some physiological and anatomical aspects of rooting 'Nabali' and 'Raseei' olive semi-hardwood stem cuttings. Acta Hortic. 773.

Bandurski, R.S., Cohen, J.D., Slovin, J.P., Reinecke, D.M., 1995. Auxin biosynthesis and metabolism. In: Plant Hormones. Springer, pp. 39-65.

Bansal, M., Nanda, K., 1981. IAA oxidase activity in relation to adventitious root formation on stem cuttings of some forest tree species. Cell. Mol. Life Sci. 37, 1273-1274.

Basak, U., Das, A., Das, P., 2000. Rooting response in stem cuttings from five species of mangrove trees: effect of auxins and enzyme activities. Mar. Biol. 136, 185-189.

Batish, D.R., Singh, H.P., Kaur, S., Kohli, R.K., Yadav, S.S., 2008. Caffeic acid affects early growth, and morphogenetic response of hypocotyl cuttings of mung bean (Phaseolus aureus). J. Plant Physiol. 165, 297-305.

Beffa, R., Martin, H.V., Pilet, P.-E., 1990. In vitro oxidation of indoleacetic acid by soluble auxin-oxidases and peroxidases from maize roots. Plant Physiol. 94, 485-491.

Chen, L.-M., Cheng, J.-T., Chen, E.-L., Yiu, T.-J., Liu, Z.-H., 2002. Naphthaleneacetic acid suppresses peroxidase activity during the induction of adventitious roots in soybean hypocotyls. J. Plant Physiol. 159, 1349-1354.

Cheniany, M., Ebrahimzadeh, H., Masoudi-nejad, A., Vahdati, K., Leslie, C., 2010. Effect of endogenous phenols and some antioxidant enzyme activities on rooting of Persian walnut (Juglans regia L.). Afr. J. Plant Sci. 4, 479-487.

Cho, H.-Y., Chang, C.-Y., Huang, L.-C., Tsai, J.-B., Liu, Z.-H., 2011. Indole-3-butyric acid suppresses the activity of peroxidase while inducing adventitious roots in Cinnamomum kanehirae. Bot. Stud. 52, 153-160.

Constabel, C.P., Barbehenn, R., 2008. Defensive roles of polyphenol oxidase in plants. In: Induced Plant Resistance to Herbivory. Springer, pp. 253-270. 
617

618

619

620

621

622

623

624

625

626

627

628

629

630

631

632

633

634

635

636

637

638

639

640

641

642

643

644

645

646

647
Dawson, J.H., 1988. Probing structure-function relations in heme-containing oxygenases and peroxidases. Science 240, 433-439.

De Klerk, G.-J., Keppel, M., Ter Brugge, J., Meekes, H., 1995. Timing of the phases in adventitous root formation in apple microcuttings. J. Exp. Bot. 46, 965-972.

Epstein, E., Lavee, S., 1984. Conversion of indole-3-butyric acid to indole-3-acetic acid by cuttings of grapevine (Vitis vinifera) and olive (Olea europea). Plant Cell Physiol. 25, 697-703.

Faivre-Rampant, O., Kevers, C., Bellini, C., Gaspar, T., 1998. Peroxidase activity, ethylene production, lignification and growth limitation in shoots of a nonrooting mutant of tobacco. Plant Physiol. Biochem. 36, 873-877.

Faivre-Rampant, O., Kevers, C., Dommes, J., Gaspar, T., 2000. The recalcitrance to rooting of the micropropagated shoots of the rac tobacco mutant: Implications of polyamines and of the polyamine metabolism. Plant Physiol. Biochem. 38, 441-448.

Fekete, S., Mándy, A., Stefanovits-Bányai, É., 2002. Change of peroxidase enzyme activities in annual cuttings during rooting. Acta Biol. Szegediensis 46, 29-31.

Fouad, M., Fayek, M., Selim, H., El-Sayed, M., 1990. Rooting of eight olive cultivars under mist. Acta Hortic. 286, 57-60.

Gaspar, T., Kevers, C., Hausman, J., Berthon, J., Ripetti, V., 1992. Practical uses of peroxidase activity as a predictive marker of rooting performance of micropropagated shoots. Agronomie 12, 757-765.

Grambow, H., Langenbeck-Schwich, B., 1983. The relationship between oxidase activity, peroxidase activity, hydrogen peroxide, and phenolic compounds in the degradation of indole-3-acetic acid in vitro. Planta 157, 132-137.

Gumiero, A., Murphy, E.J., Metcalfe, C.L., Moody, P.C., Raven, E.L., 2010. An analysis of substrate binding interactions in the heme peroxidase enzymes: a structural perspective. Arch. Biochem. Biophys. 500, 13-20.

Güneş, T., 2000. Peroxidase and IAA-oxidase activities during rooting in cuttings of three poplar species. Turk. J. Bot. 24, 97-101.

Hiraga, S., Sasaki, K., Ito, H., Ohashi, Y., Matsui, H., 2001. A large family of class III plant peroxidases. Plant Cell Physiol. 42, 462-468.

Jiménez, M., García-Carmona, F., 1999. Oxidation of the flavonol quercetin by polyphenol oxidase. J. Agr. Food Chem. 47, 56-60.

Jinyao, S., Wenlin, H., Songbo, L., Yongjun, L., Yanjun, S., 2001. Analysis of physiological and biochemical characteristics related to cutting and rooting of chimera in Populus tomentosa carr. Sci. Silvae Sin. 37, 64-67.

Kar, M., Mishra, D., 1976. Catalase, peroxidase, and polyphenoloxidase activities during rice leaf senescence. Plant Physiol. 57, 315-319.

Korasick, D.A., Enders, T.A., Strader, L.C., 2013. Auxin biosynthesis and storage forms. J. Exp. Bot. 64, $2541-2555$.

Lee, T., 1980. Effects of phenolic substances on metabolism of exogenous indole-3-acetic acid in maize stems. Physiol. Plant. 50, 107-112. 
Li, M., Huang, Z., Tan, S., Mo, X., Lin, H., Long, T., 1999. Comparison on the activities and isoenzymes of polyphenol oxidase and indoleacetic acid oxidase of difficult-and easy-to-root Eucalyptus species. Forest Res. 13, 493-500.

Li, S., Xue, L., Xu, S., Feng, H., An, L., 2007. Hydrogen peroxide involvement in formation and development of adventitious roots in cucumber. Plant Growth Regul. 52, 173-180.

Li, S.-W., Xue, L., Xu, S., Feng, H., An, L., 2009a. Mediators, genes and signaling in adventitious rooting. Bot. Rev. 75, 230-247.

Li, S.-W., Xue, L., Xu, S., Feng, H., An, L., 2009b. IBA-induced changes in antioxidant enzymes during adventitious rooting in mung bean seedlings: The role of $\mathrm{H}_{2} \mathrm{O}_{2}$. Environ. Exp. Bot. 66, 442-450.

Li, S.-W., Xue, L., Xu, S., Feng, H., An, L., 2009c. Hydrogen peroxide acts as a signal molecule in the adventitious root formation of mung bean seedlings. Environ. Exp. Bot. 65, 63-71.

Liao, W.-B., Xiao, H.-L., Zhang, M.-L., 2010. Effect of nitric oxide and hydrogen peroxide on adventitious root development from cuttings of ground-cover Chrysanthemum and associated biochemical changes. J. Plant Growth Regul. 29, 338-348.

Ljung, K., Hull, A.K., Kowalczyk, M., Marchant, A., Celenza, J., Cohen, J.D., Sandberg, G., 2002. Biosynthesis, conjugation, catabolism and homeostasis of indole-3-acetic acid in Arabidopsis thaliana. In: Auxin Molecular Biology. Springer, pp. 249-272.

Ludwig-Müller, J., 2003. Peroxidase isoenzymes as markers for the rooting ability of easy-to-root and difficult-toroot Grevillea species and cultivars of Protea obstusifolia (Proteaceae). In Vitro Cell. Dev. Biol.-Plant 39, 377383.

Ludwig-Müller, J., 2011. Auxin conjugates: their role for plant development and in the evolution of land plants. J. Exp. Bot. 62, 1757-1773.

Ludwig-Müller, J., Vertocnik, A., Town, C.D., 2005. Analysis of indole-3-butyric acid-induced adventitious root formation on Arabidopsis stem segments. J. Exp. Bot. 56, 2095-2105.

Macedo, E., Vieira, C., Carrizo, D., Porfirio, S., Hegewald, H., Arnholdt-Schmitt, B., Calado, M., Peixe, A., 2013. Adventitious root formation in olive (Olea europaea L.) microshoots: anatomical evaluation and associated biochemical changes in peroxidase and polyphenol oxidase activities. J. Hortic. Sci. Biotechnol. 88, 53-59.

Maxwell, D.P., Wang, Y., Mclntosh, L., 1999. The alternative oxidase lowers mitochondrial reactive oxygen production in plant cells. PNAS 96, 8271-8276.

Mayer, A.M., 2006. Polyphenol oxidases in plants and fungi: Going places? A review. Phytochemistry 67, 23182331.

Metaxas, D.J., Syros, T.D., Yupsanis, T., Economou, A.S., 2004. Peroxidases during adventitious rooting in cuttings of Arbutus unedo and Taxus baccata as affected by plant genotype and growth regulator treatment. Plant Growth Regul. 44, 257-266.

Molassiotis, A., Dimassi, K., Diamantidis, G., Therios, I., 2004. Changes in peroxidases and catalase activity during in vitro rooting. Biol. Plantarum 48, 1-5.

Nag, S., Saha, K., Choudhuri, M., 2001. Role of auxin and polyamines in adventitious root formation in relation to changes in compounds involved in rooting. J. Plant Growth Regul. 20, 182-194. 
Pacurar, D.I., Perrone, I., Bellini, C., 2014. Auxin is a central player in the hormone cross-talks that control adventitious rooting. Physiol. Plantarum 151, 83-96.

Passardi, F., Cosio, C., Penel, C., Dunand, C., 2005. Peroxidases have more functions than a Swiss army knife. Plant Cell Rep. 24, 255-265.

Passardi, F., Penel, C., Dunand, C., 2004. Performing the paradoxical: how plant peroxidases modify the cell wall. Trends Plant Sci. 9, 534-540.

Passardi, F., Tognolli, M., De Meyer, M., Penel, C., Dunand, C., 2006. Two cell wall associated peroxidases from Arabidopsis influence root elongation. Planta 223, 965-974.

Pastur, G.M., Zappacosta, D., Arena, M., Curvetto, N., 2001. Changes in isoperoxidase patterns during the in vitro rooting of Nothofagus antarctica. Bulg. J. Plant Physiol. 27, 43-53.

Pedreira, J., Herrera, M.T., Zarra, I., Revilla, G., 2011. The overexpression of AtPrx37, an apoplastic peroxidase, reduces growth in Arabidopsis. Physiol. Plantarum 141, 177-187.

Pedreño, M., Ros Barceló, A., Garcia-Carmona, F., Muñoz, R., 1990. Oxidation of dihydroxyfumaric acid in the absence of $\mathrm{H}_{2} \mathrm{O}_{2}$ by cell wall-bound peroxidases from lupin: a possible general model. Plant Physiol. Biochem. $28,37-42$.

Peixe, A., Raposo, A., Lourenço, R., Cardoso, H., Macedo, E., 2007. Coconut water and BAP successfully replaced zeatin in olive (Olea europaea L.) micropropagation. Sci. Hortic. 113, 1-7.

Peixe, A., Santos Macedo, E., Vieira, C.M., Arnholdt-Schmitt, B., 2010. A histological evaluation of adventitious root formation in olive (Olea europaea L. Cv. "Galega vulgar") microshoots cultured in vitro. In: 28th International Horticultural Congress, Lisbon-Portugal, August 22-27, pp S08-S214 (Abstract Book, P 379).

Popov, V., Simonian, R., Skulachev, V., Starkov, A., 1997. Inhibition of the alternative oxidase stimulates $\mathrm{H}_{2} \mathrm{O}_{2}$ production in plant mitochondria. FEBS letters 415, 87-90.

Porfirio, S., Da Silva, M.D.R., Cabrita, M.J., Azadi, P., Peixe, A., 2016a. Reviewing current knowledge on olive (Olea europaea L.) adventitious root formation. Sci. Hortic. 198, 207-226 doi: 10.1016/j.scienta.2015.11.034

Porfirio, S., Gomes da Silva, M.D.R., Peixe, A., Cabrita, M.J., Azadi, P.,2016b. Current analytical methods for plant auxin quantification - A Review. Anal. Chim. Acta 902, 8-21 doi:10.1016/j.aca.2015.10.035

Preece, J.E., 2003. A century of progress with vegetative plant propagation. HortScience 38, 1015-1025.

Qaddoury, A., Amssa, M., 2003. Endogenous phenolic contents, peroxidase and polyphenoloxidase activities in date palm (Phoenix dactylifera L.) offshoots related to rooting ability. Acta Physiol. Plantarum 25, 417-421.

Rout, G., Samantaray, S., Rout, M., Das, P., 1996. Metabolic changes during rooting in stem cuttings of Casuarina equisetifolia L.: effects of auxin, the sex and the type of cutting on rooting. Plant Growth Regul. 19, 35-43.

Rugini, E., 1984. In vitro propagation of some olive (Olea europaea sativa L.) cultivars with different root-ability, and medium development using analytical data from developing shoots and embryos. Sci. Hortic. 24, 123-134.

Santos, M.L.C., Morais, N.C., Cordeiro, A.M., 2013. As variedades de oliveira. In: Bohm, J. (ed.) O Grande Livro Da Oliveira E Do Azeite, Dinalivro editora, Lisboa, pp 174-233. 
Santos Macedo, E., Cardoso, H.G., Hernández, A., Peixe, A.A., Polidoros, A., Ferreira, A., Cordeiro, A., ArnholdtSchmitt, B., 2009. Physiologic responses and gene diversity indicate olive alternative oxidase as a potential source for markers involved in efficient adventitious root induction. Physiol. Plantarum 137, 532-552.

Santos Macedo, E., Sircar, D., Cardoso, H., Peixe, A., Arnholdt-Schmitt, B., 2012. Involvement of alternative oxidase (AOX) in adventitious rooting of Olea europaea L. microshoots is linked to adaptive phenylpropanoid and lignin metabolism. Plant Cell Rep. 1-10.

Satisha, J., Raveendran, P., Rokade, N., 2008. Changes in polyphenol oxidase activity during rooting of hardwood cuttings in three grape rootstocks under Indian conditions. S. Afr. J. Enol. Vitic. 29, 94-97.

Schopfer, P., Liszkay, A., Bechtold, M., Frahry, G., Wagner, A., 2002. Evidence that hydroxyl radicals mediate auxininduced extension growth. Planta 214, 821-828.

Siegel, B., 1993. Plant peroxidases-an organismic perspective. Plant Growth Regul. 12, 303-312.

Sircar, D., Cardoso, H.G., Mukherjee, C., Mitra, A., Arnholdt-Schmitt, B., 2012. Alternative oxidase (AOX) and phenolic metabolism in methyl jasmonate-treated hairy root cultures of Daucus carota L. J. Plant Physiol. 169, 657-663.

Strader, L.C., Bartel, B., 2011. Transport and metabolism of the endogenous auxin precursor indole-3-butyric acid. Molecular Plant 4, 477-486.

Strader, L.C., Wheeler, D.L., Christensen, S.E., Berens, J.C., Cohen, J.D., Rampey, R.A., Bartel, B., 2011. Multiple facets of Arabidopsis seedling development require indole-3-butyric acid-derived auxin. Plant Cell 23, 984-999.

Syros, T., Yupsanis, T., Zafiriadis, H., Economou, A., 2004. Activity and isoforms of peroxidases, lignin and anatomy, during adventitious rooting in cuttings of Ebenus cretica L. J. Plant Physiol. 161, 69-77.

Tartoura, K., Da Rocha, A., Youssef, S., 2004. Synergistic interaction between coumarin 1, 2-benzopyrone and indole-3-butyric acid in stimulating adventitious root formation in Vigna radiata (L.) Wilczek cuttings: I. Endogenous free and conjugated IAA and basic isoperoxidases. Plant Growth Regul. 42, 253-262.

Tonon, G., Kevers, C., Gaspar, T., 2001. Changes in polyamines, auxins and peroxidase activity during in vitro rooting of Fraxinus angustifolia shoots: an auxin-independent rooting model. Tree Physiol. 21, 655-663.

Tzika, E.D., Sotiroudis, T.G., Papadimitriou, V., Xenakis, A., 2009. Partial purification and characterization of peroxidase from olives (Olea europaea cv. Koroneiki). Eur. Food Res. Technol. 228, 487-495.

Van Aken, O., Giraud, E., Clifton, R., Whelan, J., 2009. Alternative oxidase: a target and regulator of stress responses. Physiol. Plantarum 137, 354-361.

Vanholme, R., Demedts, B., Morreel, K., Ralph, J., Boerjan, W., 2010. Lignin biosynthesis and structure. Plant Physiol. 153, 895-905.

Vatulescu, A.D., Fortunato, A.S., Sá, M.C., Amâncio, S., Ricardo, C.P., Jackson, P.A., 2004. Cloning and characterisation of a basic IAA oxidase associated with root induction in Vitis vinifera. Plant Physiol. Biochem. 42, 609-615.

Vogt, T., 2010. Phenylpropanoid biosynthesis. Molecular Plant 3, 2-20.

Wiesman, Z., Riov, J., Epstein, E., 1989. Characterization and rooting ability of indole-3-butyric acid conjugates formed during rooting of mung bean cuttings. Plant Physiol. 91, 1080-1084. 
Zhang, S., Wu, J., Yuan, D., Zhang, D., Huang, Z., Xiao, L., Yang, C., 2014. Perturbation of auxin homeostasis caused by mitochondrial $\mathrm{FtSH} 4$ gene-mediated peroxidase accumulation regulates Arabidopsis architechture. Molecular Plant 7(5), 856-73.

Zolman, B.K., Martinez, N., Millius, A., Adham, A.R., Bartel, B., 2008. Identification and characterization of Arabidopsis indole-3-butyric acid response mutants defective in novel peroxisomal enzymes. Genetics 180, 237-251.

Zolman, B.K., Nyberg, M., Bartel, B., 2007. IBR3, a novel peroxisomal acyl-CoA dehydrogenase-like protein required for indole-3-butyric acid response. Plant Mol. Biol. 64, 59-72. 